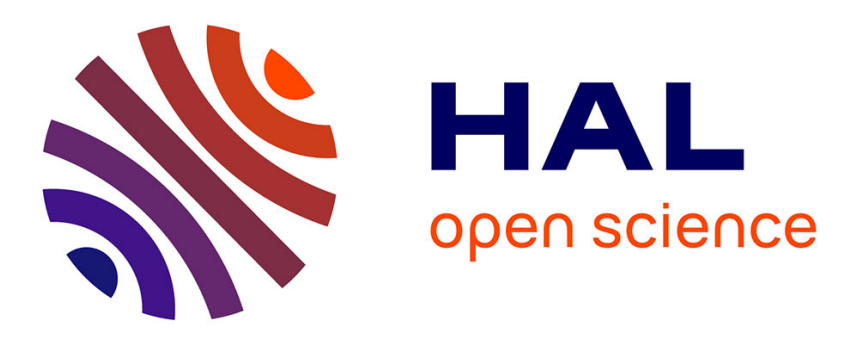

\title{
Modeling the platinum-catalyzed intermolecular hydroamination of ethylene: The nucleophilic addition of HNEt2 to coordinated ethylene in trans-PtBr2(C2H4)(HNEt2)
}

Pavel Dub, Jean-Claude Daran, Vladislava A. Levina, Natalia V Belkova, Elena S. Shubina, Rinaldo Poli

\section{To cite this version:}

Pavel Dub, Jean-Claude Daran, Vladislava A. Levina, Natalia V Belkova, Elena S. Shubina, et al.. Modeling the platinum-catalyzed intermolecular hydroamination of ethylene: The nucleophilic addition of HNEt2 to coordinated ethylene in trans-PtBr2(C2H4)(HNEt2). Journal of Organometallic Chemistry, 2011, 696 (6), pp.1174-1183. 10.1016/j.jorganchem.2010.09.043 . hal-03158368

\author{
HAL Id: hal-03158368 \\ https://hal.science/hal-03158368
}

Submitted on 3 Mar 2021

HAL is a multi-disciplinary open access archive for the deposit and dissemination of scientific research documents, whether they are published or not. The documents may come from teaching and research institutions in France or abroad, or from public or private research centers.
L'archive ouverte pluridisciplinaire HAL, est destinée au dépôt et à la diffusion de documents scientifiques de niveau recherche, publiés ou non, émanant des établissements d'enseignement et de recherche français ou étrangers, des laboratoires publics ou privés. 


\section{Modeling the platinum-catalyzed intermolecular hydroamination of ethylene: the nucleophilic addition of $\mathrm{HNEt}_{2}$ to coordinated ethylene in trans-PtBr $2\left(\mathrm{C}_{2} \mathrm{H}_{4}\right)\left(\mathrm{HNEt}_{2}\right)$}

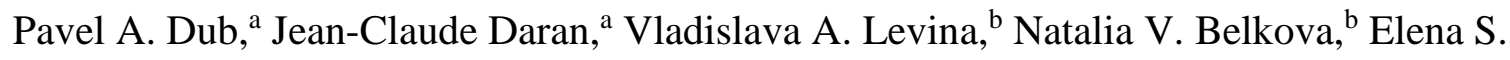
Shubina $^{\mathrm{b}}$ and Rinaldo Poli*,a,c

${ }^{\mathrm{a} C N R S ;}$ LCC (Laboratoire de Chimie de Coordination); Université de Toulouse; UPS, INPT; 205, route de Narbonne, F-31077 Toulouse, France; Fax: (+) 33-561553003; Email: rinaldo.poli@lcc-toulouse.fr

${ }^{b}$ A. N. Nesmeyanov Institute of Organoelement Compounds, Russian Academy of Sciences, Vavilov Street 28, 119991 Moscow, Russia.

${ }^{c}$ Institut Universitaire de France, 103, bd Saint-Michel, 75005 Paris, France 


\section{Abstract}

Compound trans $-\mathrm{PtBr}_{2}\left(\mathrm{C}_{2} \mathrm{H}_{4}\right)\left(\mathrm{NHEt}_{2}\right)$ (1) has been synthesized by $\mathrm{Et}_{2} \mathrm{NH}$ addition to $\mathrm{K}\left[\mathrm{PtBr}_{3}\left(\mathrm{C}_{2} \mathrm{H}_{4}\right)\right]$ and structurally characterized. Its isomer cis- $\mathrm{PtBr}_{2}\left(\mathrm{C}_{2} \mathrm{H}_{4}\right)\left(\mathrm{NHEt}_{2}\right)(3)$ has been obtained from 1 by photolytic dissociation of ethylene, generating the dinuclear trans- $\left[\mathrm{PtBr}_{2}\left(\mathrm{NHEt}_{2}\right)\right]_{2}$ intermediate (2), followed by thermal re-addition of $\mathrm{C}_{2} \mathrm{H}_{4}$, but only in low yields. The addition of further $\mathrm{Et}_{2} \mathrm{NH}$ to $\mathbf{1}$ in either dichloromethane or acetone yields the zwitterionic complex trans- $\mathrm{Pt}^{(-)} \mathrm{Br}_{2}\left(\mathrm{NHEt}_{2}\right)\left(\mathrm{CH}_{2} \mathrm{CH}_{2} \mathrm{~N}^{(+)} \mathrm{HEt}_{2}\right)$ (4) within the time of mixing in an equilibrated process, which shifts toward the product at lower temperatures $\left(\Delta \mathrm{H}^{\circ}=-6.8 \pm 0.5 \mathrm{kcal} / \mathrm{mol}, \Delta \mathrm{S}^{\circ}=-14.0 \pm 2.0\right.$ e.u., from a variable temperature IR study). ${ }^{1} \mathrm{H}$ NMR shows that free $\mathrm{Et}_{2} \mathrm{NH}$ exchanges rapidly with $\mathrm{H}$-bonded amine in a 4. $\mathrm{NHEt}_{2}$ adduct, slowly with the coordinated $\mathrm{Et}_{2} \mathrm{NH}$ in $\mathbf{1}$, and not at all (on the NMR time scale) with $\mathrm{Pt}_{-} \mathrm{NHEt}_{2}$ or $-\mathrm{CH}_{2} \mathrm{CH}_{2} \mathrm{~N}^{(+)} \mathrm{HEt}_{2}$ in 4. No evidence was obtained for deprotonation of 4 to yield an aminoethyl derivative trans-[ $\left.\mathrm{PtBr}_{2}\left(\mathrm{NHEt}_{2}\right)\left(\mathrm{CH}_{2} \mathrm{CH}_{2} \mathrm{NEt}_{2}\right)\right]^{-}$ (5), except as an intermediate in the averaging of the diasteretopic methylene protons of the $\mathrm{CH}_{2} \mathrm{CH}_{2} \mathrm{~N}^{(+)} \mathrm{HEt}_{2}$ ligand of 4 in the higher polarity acetone solvent. Computational work by DFT attributes this phenomenon to more facile ion pair dissociation of $\mathbf{5} \cdot \mathrm{Et}_{2} \mathrm{NH}_{2}{ }^{+}$, obtained from $4 \cdot \mathrm{Et}_{2} \mathrm{NH}$, facilitating inversion at the $\mathrm{N}$ atom. Complex $\mathbf{4}$ is the sole observable product initially but slow decomposition occurs in both solvents, though in different ways, without observable generation of $\mathrm{NEt}_{3}$. Addition of $\mathrm{TfOH}$ to equilibrated solutions of 4, 1 and excess $\mathrm{Et}_{2} \mathrm{NH}$ leads to partial protonolysis to yield $\mathrm{NEt}_{3}$ but also regenerates 1 through a shift of the equilibrium via protonation of free $\mathrm{Et}_{2} \mathrm{NH}$. The DFT calculations reveal also a more favourable coordination (stronger $\mathrm{Pt}-\mathrm{N}$ bond) of $\mathrm{Et}_{2} \mathrm{NH}$ relative to $\mathrm{PhNH}_{2}$ to the $\mathrm{Pt}^{\mathrm{II}}$ center, but the barriers of the nucleophilic additions of $\mathrm{Et}_{2} \mathrm{NH}$ to the $\mathrm{C}_{2} \mathrm{H}_{4}$ ligand in $\mathbf{1}$ and of $\mathrm{PhNH}_{2}$ to trans $-\mathrm{PtBr}_{2}\left(\mathrm{C}_{2} \mathrm{H}_{4}\right)\left(\mathrm{PhNH}_{2}\right)(\mathbf{1 a})$ are predicted to be essentially identical for the two systems. 


\section{Keywords}

Platinum, diethylamine complexes, olefin complexes, nucleophilic addition, hydroamination. 


\section{Introduction}

A number of contributions have appeared in recent years on the intermolecular hydroamination of non-activated olefins catalysed by Pt-based systems [1-8]. The first step in these transformations is believed to be the nucleophilic addition of the amine to the coordinated olefin in a $\mathrm{Pt}^{\mathrm{II}}$ derivative to afford a zwitterionic complex $\mathrm{L}_{3} \mathrm{Pt}^{(-)}-\mathrm{CH}_{2}-\mathrm{CH}_{2}-$ $\mathrm{N}^{(+)} \mathrm{HR}_{2}$ [5, 9]. A recent computational study of the addition of aniline to ethylene catalyzed by $\mathrm{PtBr}_{2} / \mathrm{Br}^{-}$was found to involve the resting state complex $\left[\mathrm{PtBr}_{3}\left(\mathrm{C}_{2} \mathrm{H}_{4}\right)\right]^{-}$and a variety of off-loop species also containing a $\mathrm{Pt}^{\mathrm{II}}$-coordinated ethylene ligand [10]. The amine addition reaction has been very well studied experimentally for basic amines and $\mathrm{PtCl}_{2}$ derivatives such as trans- $\mathrm{PtCl}_{2}$ (olefin)(am) or cis- $\mathrm{PtCl}_{2}\left(\mathrm{C}_{2} \mathrm{H}_{4}\right)(\mathrm{Y})\left(\mathrm{Y}=\mathrm{PR}_{3}\right.$, py, $\mathrm{NH}_{3}$, am, DMSO; am = amine) [11-15] (Scheme 1) and monochloride complexes such as $\left[\mathrm{PtCl}(\right.$ alkene $)(\text { tmeda) }]^{+}[16]$ or $\mathrm{PtCl}(\mathrm{PyPyr})\left(\mathrm{C}_{2} \mathrm{H}_{4}\right)$ [17], but no evidence of addition was found when the amine is not sufficient basic $\left(\mathrm{pK}_{\mathrm{a}}<5\right.$ for the conjugate ammonium ion). It has also been shown that basic amines add reversibly and exothermically to coordinated ethylene [15], but the system may slowly lead to irreversible transformations at room temperature, occasionally accompanied by the formation of $\mathrm{Pt}^{0}$ [18]. For instance, the zwitterionic complexes resulting from the nucleophilic addition to the above mentioned cis- $\mathrm{PtCl}_{2}\left(\mathrm{C}_{2} \mathrm{H}_{4}\right)(\mathrm{Y})$ may lead to the formation of platinaazacycles [13] or other ligand substitution processes, see Scheme $1[13,16]$, whereas only decomposition was observed for the trans $-\mathrm{PtCl}_{2}\left(\mathrm{C}_{2} \mathrm{H}_{4}\right)(\mathrm{am})$ isomer [19]. The cis/trans isomerisation is usually a slow process for these complexes $[11,20]$. 


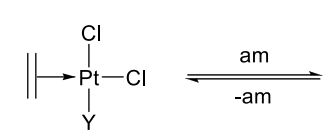

$\mathrm{Y}=\mathrm{PR}_{3}, \mathrm{py}, \mathrm{NH}_{3}, \mathrm{am}, \mathrm{Me}_{2} \mathrm{SO}$

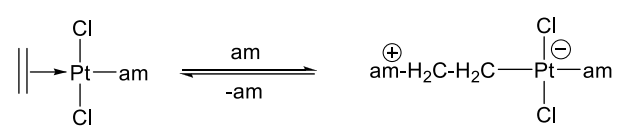

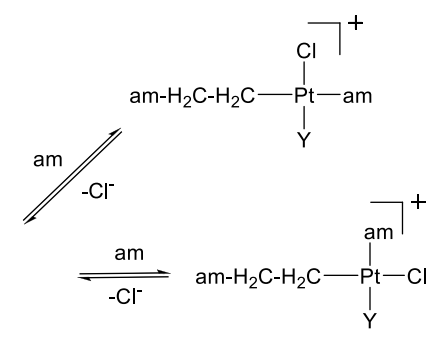

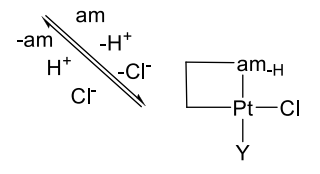

\section{Scheme 1}

It is notable that no Pt-catalyzed hydroamination is reported for amines that lead to experimentally observable nucleophilic addition to Pt-coordinated ethylene, whereas no nucleophilic addition products are experimentally observable for amines that give catalytic hydroamination. Moreover, the turnover number for the $\mathrm{PtBr}_{2} / \mathrm{Br}^{-}$-catalyzed hydroamination of $\mathrm{C}_{2} \mathrm{H}_{4}$ by $\mathrm{ArNH}_{2}$ is inversely proportional to the amine basicity (for instance, 22 for $\mathrm{Ar}=4-\mathrm{MeOC}_{6} \mathrm{H}_{4}$ with a pKa for the conjugated acid of 5.34 and 110 for $\mathrm{Ar}=2-\mathrm{ClC}_{6} \mathrm{H}_{4}$ with a pK $\mathrm{a}_{\mathrm{a}}$ of 2.65) [1].

We have recently reported experimental and theoretical studies on the hydroamination of ethylene by aniline $[7,8,10,21]$. The catalytic system consisting of $\mathrm{PtX}_{2} / \mathrm{X}^{-}$shows the best activity for $\mathrm{X}=\mathrm{Br}$. The reaction between complexes trans or cis$\mathrm{PtBr}_{2}\left(\mathrm{C}_{2} \mathrm{H}_{4}\right)\left(\mathrm{PhNH}_{2}\right)$ and $\mathrm{PhNH}_{2}\left(\mathrm{pK}_{\mathrm{a}}=4.63\right)$ does not give observable nucleophilic addition products at temperatures up to $68^{\circ} \mathrm{C}$. The present paper reports the investigation of model stoichiometric processes involving the more basic amine $\mathrm{Et}_{2} \mathrm{NH}\left(\mathrm{pK}_{\mathrm{a}}\right.$ of conjugated acid $=11.02)$ and the $\mathrm{PtBr}_{2} / \mathrm{Br}^{-}$catalytic system. We will compare the reactivity of complexes trans- $\mathrm{PtBr}_{2}\left(\mathrm{C}_{2} \mathrm{H}_{4}\right)\left(\mathrm{HNEt}_{2}\right)(\mathbf{1})$ and trans $-\mathrm{PtBr}_{2}\left(\mathrm{C}_{2} \mathrm{H}_{4}\right)\left(\mathrm{PhNH}_{2}\right)$ (1a) towards an excess of the corresponding amine, in an effort to understand the role of the amine basicity and the presence of added acids to the hydroamination catalytic activity. 
General. All solvents were of HPLC grade and were used as received. $\mathrm{HNEt}_{2}$ (Fluka) was distilled and kept under argon in the dark. $\mathrm{K}\left[\mathrm{PtCl}_{3}\left(\mathrm{C}_{2} \mathrm{H}_{4}\right)\right] \cdot \mathrm{H}_{2} \mathrm{O}$ (Aldrich) was used as received. Ethylene (purity $\geq 99.5 \%$ ) was purchased from Air Liquide.

Instrumentation. NMR investigations were carried out on Bruker DPX300 (and AV400) spectrometers operating at 300.1 (400.1) $\mathrm{MHz}\left({ }^{1} \mathrm{H}\right), 75.47$ (100.6) $\mathrm{MHz}\left({ }^{13} \mathrm{C}\right)$ and 64.5 MHz $\left({ }^{195} \mathrm{Pt}\right)$. Low-temperature NMR investigations were carried out on a Bruker AV500 spectrometer, operating at $500.3\left({ }^{1} \mathrm{H}\right)$ and $125.8 \mathrm{MHz}\left({ }^{13} \mathrm{C}\right)$ and $107.2 \mathrm{MHz}\left({ }^{195} \mathrm{Pt}\right)$, respectively. The spectra were calibrated with the residual solvent resonance relative to TMS $\left({ }^{1} \mathrm{H},{ }^{13} \mathrm{C}\right)$ and $\mathrm{Na}_{2} \mathrm{PtCl}_{6}\left({ }^{195} \mathrm{Pt}\right)$. The NMR studies were performed either in air or under argon, showing no difference. IR spectra were recorded on a Perkin-Elmer Spectrum 100 FTIR spectrometer for neat compounds $\left(4000-600 \mathrm{~cm}^{-1} ; 2 \mathrm{~cm}^{-1}\right.$ resolution) and on a Nicolet FTIR spectrometer for solutions in $\mathrm{CaF}_{2}$ cells. A Carl Zeiss Jena cryostat was used for variable temperature measurements; the accuracy of the experimental temperature adjustment was $\pm 1 \mathrm{~K}$. Elemental analyses were performed by the Microanalytical Service of the Laboratoire de Chimie de Coordination. Other characterization data (NMR in other solvents, UV-visible, IR) are given in the Supporting Information.

Synthesis of trans-PtBr $2\left(\mathbf{C}_{2} \mathbf{H}_{4}\right)\left(\right.$ HNEt $\left._{2}\right)$, 1. An aqueous solution (16 mL) of Zeise's salt $(500 \mathrm{mg}, 1.36 \mathrm{mmol})$ and $\mathrm{KBr}(8 \mathrm{~g}, 50$ equiv) was stirred under an ethene flush overnight at room temperature. $\mathrm{An}_{2} \mathrm{NH}(140 \mu \mathrm{L}, 1.36 \mathrm{mmol})$ solution in $\mathrm{EtOH}(4 \mathrm{ml})$ was then added dropwise, yielding a yellow precipitate. After stirring for $1 \mathrm{~h}$ at room temperature, the yellow precipitate was filtered, washed with water, dried in vacuo, redissolved in dichloromethane, filtered and again dried in vacuo (467 mg, $75 \%$ ). The compound was stored in the dark at low temperature under argon. Elem. anal. \% Calcd. for $\mathrm{C}_{6} \mathrm{H}_{15} \mathrm{Br}_{2} \mathrm{NPt}$ : C, 15.80; H, 3.32; N, 3.07. \% Found: C, 15.87; H, 3.28; N, 3.07. IR (neat, $\left.\mathrm{cm}^{-1}\right): 3198(\mathrm{~N}-\mathrm{H}), 1518\left(\delta\left(\mathrm{C}_{2} \mathrm{H}_{4}\right)+v\left(\mathrm{C}_{2} \mathrm{H}_{4}\right)\right), 1249\left(v\left(\mathrm{C}_{2} \mathrm{H}_{4}\right)+\delta\left(\mathrm{C}_{2} \mathrm{H}_{4}\right)\right)$. NMR (acetone$\left.d_{6}\right):{ }^{1} \mathrm{H}\left(300.13 \mathrm{MHz}, \delta\right.$ ): 5.62 (br with Pt satellites, $1 \mathrm{H}, \mathrm{NH},{ }^{2} \mathrm{~J}_{\mathrm{Pt}-\mathrm{H}}$ ca. $90 \mathrm{~Hz}$ ), 4.68 (s with 
Pt satellites, $\left.{ }^{2} J_{\mathrm{H}-\mathrm{Pt}}=60 \mathrm{~Hz}, 4 \mathrm{H}, \mathrm{C}_{2} \mathrm{H}_{4}\right), 3.35\left(\mathrm{~m}, 2 \mathrm{H}, \mathrm{HNCH}_{2}\right), 3.13\left(\mathrm{~m}, 2 \mathrm{H}, \mathrm{HNCH}_{2}\right), 1.52$ $\left(\mathrm{t},{ }^{3} \mathrm{~J}_{\mathrm{H}-\mathrm{H}}=7 \mathrm{~Hz}, 6 \mathrm{H}, \mathrm{HN}\left(\mathrm{CH}_{2} \mathrm{CH}_{3}\right)_{2}\right) .{ }^{13} \mathrm{C}\left\{{ }^{1} \mathrm{H}\right\} \quad(75.5 \mathrm{MHz}, \delta): 70.7$ (s with Pt satellites, ${ }^{1} J_{\mathrm{C}-}$ $\mathrm{Pt}=153 \mathrm{~Hz}, \mathrm{C}_{2} \mathrm{H}_{4}$ ), 50.0 (s with Pt satellites, $\mathrm{HNCH}_{2},{ }^{1} J_{\mathrm{C}-\mathrm{Pt}}=14 \mathrm{~Hz}$ ), 14.0 (s with Pt satellites, $\left.\mathrm{HN}\left(\mathrm{CH}_{2} \mathrm{CH}_{3}\right)_{2},{ }^{1} J_{\mathrm{C}-\mathrm{Pt}}=8 \mathrm{~Hz}\right) .{ }^{195} \mathrm{Pt}(64.5 \mathrm{MHz}, \delta):-3456\left(\mathrm{br}\right.$ tr, $\left.{ }^{1} J_{\mathrm{Pt}-\mathrm{N}}=218 \mathrm{~Hz}\right)$. For the NMR properties in other solvents, see SI.

Synthesis of trans-Pt $\mathbf{P r}_{\mathbf{4}}\left(\mathbf{H N E t}_{2}\right)$ 2, 2. Compound $\mathbf{1}(150 \mathrm{mg}, 0.175 \mathrm{mmol})$ was dissolved in a mixture of $\mathrm{CHCl}_{3}(\mathrm{ca} .300 \mu \mathrm{l})$ and petroleum ether $(1.2 \mathrm{ml})$. The solution was irradiated with UV-light. After $18 \mathrm{~h}$ the colorless solution was decanted off from formed red-orange precipitate, which was then washed with pentane and dried in vacuo (132 mg, 94\%). Elem. anal. \% calc. for $\mathrm{C}_{8} \mathrm{H}_{22} \mathrm{Br}_{4} \mathrm{~N}_{2} \mathrm{Pt}_{2}, \mathrm{C}, 11.22 ; \mathrm{H}, 2.59 ; \mathrm{N}, 3.27$. \% Found: C, 12.03; H, 2.63; N, 3.26. IR (neat, $\left.\mathrm{cm}^{-1}\right): 3183(\mathrm{~N}-\mathrm{H})$. NMR (acetone- $\left.d_{6}\right):{ }^{1} \mathrm{H}$

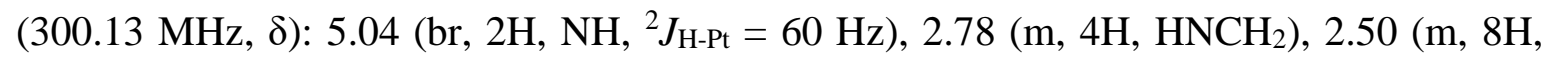
$\left.\mathrm{HNCH}_{2},{ }^{4} \mathrm{~J}_{\mathrm{H}-\mathrm{Pt}}=62 \mathrm{~Hz}\right), 1.65\left(\mathrm{t},{ }^{3} \mathrm{~J}_{\mathrm{H}-\mathrm{H}}=7 \mathrm{~Hz}, 12 \mathrm{H}, \mathrm{HN}\left(\mathrm{CH}_{2} \mathrm{CH}_{3}\right)_{2}\right) ;{ }^{13} \mathrm{C}\left\{{ }^{1} \mathrm{H}\right\}(75.5 \mathrm{MHz}$, d): 68.2 (s with Pt satellites, ${ }^{1} J_{\mathrm{C}-\mathrm{Pt}}=153 \mathrm{~Hz}, \mathrm{C}_{2} \mathrm{H}_{4}$ ), 50.0 (s with Pt satellites, $\mathrm{HNCH}_{2},{ }^{1} J_{\mathrm{C}-\mathrm{Pt}}$ $=13 \mathrm{~Hz}), 13.5$ (s with Pt satellites, $\left.\mathrm{HN}\left(\mathrm{CH}_{2} \mathrm{CH}_{3}\right)_{2},{ }^{1} \mathrm{~J}_{\mathrm{C}-\mathrm{Pt}}=8 \mathrm{~Hz}\right) .{ }^{195} \mathrm{Pt}(64.5 \mathrm{MHz}, \delta)$ : 2210 (br).

Preparation of cis-PtBr $2\left(\mathbf{C}_{2} \mathbf{H}_{4}\right)\left(\mathbf{H N E t}_{2}\right)$, 3. Compound 2 (100 mg) was suspended in $\mathrm{CHCl}_{3}(4 \mathrm{~mL})$ and hexane $(4 \mathrm{ml})$ and the mixture was treated with an ethylene stream in the dark. After $18 \mathrm{~h}$, the ${ }^{1} \mathrm{H}$ NMR spectrum showed only small changes relative to the starting material. After 4 days a small amount of grey precipitate had formed while the colour of solution was slightly green. The precipitate was filtered off, washed with $\mathrm{CHCl}_{3}$ and dried (16 mg, $15 \%$ ). Elem. anal. \% calc. for $\mathrm{C}_{6} \mathrm{H}_{15} \mathrm{Br}_{2} \mathrm{NPt}$ : C, 15.80; H, 3.32; N, 3.07 . \% Found: C, 16.95; H, 3.18; N, 2.83. IR (neat, $\left.\mathrm{cm}^{-1}\right): 3164(\mathrm{~N}-\mathrm{H})$. NMR (acetone- $\left.d_{6}\right):{ }^{1} \mathrm{H}$ (300.13 MHz, $\delta): 4.50\left(\mathrm{br}, 4 \mathrm{H}, \mathrm{C}_{2} H_{4}\right), 3.76\left(1 \mathrm{H}, \mathrm{NH},{ }^{2} J_{\mathrm{H}-\mathrm{Pt}}=60 \mathrm{~Hz}\right) 3.30(\mathrm{~m}, 2 \mathrm{H}$, $\left.\mathrm{HNCH}_{2}\right), 2.80\left(\mathrm{~m}, 2 \mathrm{H}, \mathrm{HNCH}_{2},{ }^{4} \mathrm{~J}_{\mathrm{H}-\mathrm{Pt}}=62 \mathrm{~Hz}\right), 1.43\left(\mathrm{t},{ }^{3} \mathrm{~J}_{\mathrm{H}-\mathrm{H}}=7 \mathrm{~Hz}, 6 \mathrm{H}, \mathrm{HN}\left(\mathrm{CH}_{2} \mathrm{CH}_{3}\right)_{2}\right)$. ${ }^{13} \mathrm{C}\left\{{ }^{1} \mathrm{H}\right\}\left(75.5 \mathrm{MHz}, \delta\right.$ ): 68.2 (s with Pt satellites, ${ }^{1} J_{\mathrm{C}-\mathrm{Pt}}=185 \mathrm{~Hz}, \mathrm{C}_{2} \mathrm{H}_{4}$ ), 50.0 (s with Pt 
satellites, $\mathrm{HNCH}_{2},{ }^{1} J_{\mathrm{C}-\mathrm{Pt}}=15 \mathrm{~Hz}$ ), 13.5 (s with Pt satellites, $\mathrm{HN}\left(\mathrm{CH}_{2} \mathrm{CH}_{3}\right)_{2},{ }^{1} J_{\mathrm{C}-\mathrm{Pt}}=8 \mathrm{~Hz}$ ). ${ }^{195} \mathrm{Pt}(64.5 \mathrm{MHz}, \delta):-3059$ (br tr, $\mathrm{J}=213 \mathrm{~Hz}$ ). The compound slowly decomposes in solution with the formation of black particles.

Computational details. All geometry optimizations were carried out on isolated molecules in the gas phase by the DFT approach with the Gaussian03 suite of programs [22] using the B3LYP functional [23-25]. All molecules described in this work are diamagnetic with the paramagnetic excited states expected at much higher energy, thus the typical problem of the overestimation of spin polarization shown by hybrid functionals [26] does not negatively affect our calculations. All atoms except Pt were described by the standard 6-31+G* basis set, which includes both polarization and diffuse functions that are necessary to allow angular and radial flexibility to the highly anionic systems. The Pt atom was described by the LANL2TZ(f) basis, which is an uncontracted version of LANL2DZ and includes an $\mathrm{f}$ polarization function and an ECP [27]. Frequency calculations were carried out for all optimized geometries in order to verify their nature as local minima, for the calculation of thermodynamic parameters at $298.15 \mathrm{~K}$ under the ideal gas and harmonic approximations, and for the identification of all transition states (one imaginary frequency). Solvent effects were introduced by means of C-PCM [28, 29] single point calculations on the gas-phase optimized geometries in dichloromethane $(\varepsilon=8.93)$ and acetone $(\varepsilon=20.49)$. Among various continuum solvent models, the C-PCM was selected because of its generally better performance [30-32], even though there remains an inherent error when working with charged species [30]. The solvent cavity was created by a series of overlapping spheres by the default UA0 model and all standard settings as implemented in Gaussian03 were used for the C-PCM calculations. The reaction free energy changes in solution were corrected for the change of standard state from the gas phase (1 atm) to solution (1 M) [33]. 
X-ray crystallography. A single crystal of each compound was mounted under inert perfluoropolyether at the tip of a glass fibre and cooled in the cryostream of an OxfordDiffraction XCALIBUR CCD diffractometer. Data were collected using the monochromatic MoK $\alpha$ radiation $(\lambda=0.71073)$. The structures were solved by direct methods (SIR97) [34] and refined by least-squares procedures on $F^{2}$ using SHELXL-97 [35]. All $\mathrm{H}$ atoms attached to carbon were introduced in idealised positions and treated as riding on their parent atoms in the calculations except for the $\mathrm{H}$ attached to the ethylene group which were refined using restraints. The drawing of the molecules was realised with the help of ORTEP3 [36]. Crystal data and refinement parameters are collected in Table 1, while relevant bond distances and angles are given in Table 2. Crystallographic data (excluding structure factors) have been deposited with the Cambridge Crystallographic Data Centre as supplementary publication no. CCDC $784685 \& 784686$. Copies of the data can be obtained free of charge on application to the Director, CCDC, 12 Union Road, Cambridge CB2 1EZ, UK (fax: (+44) 1223-336-033; e-mail: deposit@ ccdc.cam.ac.uk).

Table 1. Crystal data and structure refinement for compounds $\mathbf{1}$ and $\mathbf{2}$.

\begin{tabular}{lll}
\hline Identification code & \multicolumn{1}{c}{$\mathbf{1}$} & \multicolumn{1}{c}{$\mathbf{2}$} \\
\hline Empirical formula & $\mathrm{C}_{6} \mathrm{H}_{15} \mathrm{Br}_{2} \mathrm{NPt}$ & $\mathrm{C}_{8} \mathrm{H}_{22} \mathrm{Br}_{4} \mathrm{~N}_{2} \mathrm{Pt}_{2}$ \\
Formula weight & 456.10 & 856.10 \\
Temperature, $\mathrm{K}$ & $180(2)$ & $180(2)$ \\
Crystal system & Monoclinic & Monoclinic \\
Space group & $\mathrm{P} 2{ }_{1} / \mathrm{n}$ & $\mathrm{P} 2{ }_{1} / \mathrm{n}$ \\
$\mathrm{a}, \AA$ & $11.0458(4)$ & $7.1779(3)$ \\
$\mathrm{b}, \AA$ & $8.7461(3)$ & $11.6622(4)$ \\
$\mathrm{c}, \AA$ & $11.5095(4)$ & $10.3715(4)$ \\
$\alpha,{ }^{\circ}$ & 90 & 90.0 \\
$\beta,{ }^{\circ}$ & $102.881(4)$ & $100.113(2)$ \\
$\gamma,{ }^{\circ}$ & 90 & 90.0 \\
$\mathrm{~V}, \AA^{3}$ & $1083.92(7)$ & $854.71(6)$ \\
$\mathrm{Z}$ & 4 & 2 \\
Dcalc, $\mathrm{Mg} / \mathrm{m}^{3}$ & 2.795 & 3.326
\end{tabular}




\begin{tabular}{|c|c|c|}
\hline$\mu, \mathrm{mm}-1$ & 20.259 & 25.680 \\
\hline $\mathrm{F}(000)$ & 824 & 760 \\
\hline Crystal size, mm3 & $0.25 \times 0.23 \times 0.18$ & $0.38 \times 0.32 \times 0.26$ \\
\hline$\theta^{\circ}$, range & 2.90 to 28.28 & 3.37 to 30.0 \\
\hline Reflections collected & 9325 & 11378 \\
\hline Unique reflections [Rint] & $2683[0.0380]$ & $2489[0.0683]$ \\
\hline Obsd reflections $[\mathrm{I}>2 \sigma(\mathrm{I})]$ & 100.0 & 2215 \\
\hline Completness & $0.25 \times 0.23 \times 0.18$ & 99.5 \\
\hline Absorption correction & Multi-scan & Multi-scan \\
\hline $\mathrm{T}_{\min } / T_{\max }$ & $0.231 / 1 / 0$ & $0.28744 / 1.0$ \\
\hline parameters & 108 & 76 \\
\hline GOF on $\mathrm{F}^{2}$ & 0.979 & 1.005 \\
\hline $\mathrm{R} 1, \mathrm{wR} 2[\mathrm{I}>2 \sigma(\mathrm{I})]$ & $0.0257,0.0557$ & $0.0292,0.0728$ \\
\hline R1, wR2 (all data) & $0.0346,0.0574$ & $0.0348,0.0761$ \\
\hline$\Delta \rho_{\min ,}, \Delta \rho_{\max }\left(\mathrm{e} \AA^{-3}\right)$ & $-1.970,2.066$ & $-3.060,1.883$ \\
\hline
\end{tabular}

Table 2. Relevant bond lengths $[\AA]$ and angles $\left[{ }^{\circ}\right]$ for compounds $\mathbf{1}$ and $\mathbf{2}$.

Compound 1

\begin{tabular}{|c|c|c|c|}
\hline \multicolumn{4}{|l|}{ Distances } \\
\hline $\operatorname{Pt}(1)-\mathrm{N}(1)$ & $2.089(4)$ & $\operatorname{Pt}(1)-C(1)$ & $2.146(6)$ \\
\hline $\operatorname{Pt}(1)-\operatorname{Br}(1)$ & $2.4191(5)$ & $\operatorname{Pt}(1)-\mathrm{C}(2)$ & $2.158(5)$ \\
\hline $\operatorname{Pt}(1)-\operatorname{Br}(2)$ & $2.4201(6)$ & $C(1)-C(2)$ & $1.356(9)$ \\
\hline \multicolumn{4}{|l|}{ Angles } \\
\hline $\mathrm{N}(1)-\operatorname{Pt}(1)-\mathrm{C}(1)$ & $156.9(2)$ & $\mathrm{C}(2)-\operatorname{Pt}(1)-\mathrm{Br}(1)$ & $91.26(17)$ \\
\hline $\mathrm{N}(1)-\operatorname{Pt}(1)-\mathrm{C}(2)$ & $166.3(2)$ & $\mathrm{N}(1)-\operatorname{Pt}(1)-\mathrm{Br}(2)$ & $90.66(11)$ \\
\hline $\mathrm{C}(1)-\mathrm{Pt}(1)-\mathrm{C}(2)$ & $36.7(2)$ & $\mathrm{C}(1)-\operatorname{Pt}(1)-\mathrm{Br}(2)$ & $90.69(17)$ \\
\hline $\mathrm{N}(1)-\operatorname{Pt}(1)-\mathrm{Br}(1)$ & $87.60(11)$ & $\mathrm{C}(2)-\operatorname{Pt}(1)-\mathrm{Br}(2)$ & $89.88(17)$ \\
\hline $\mathrm{C}(1)-\operatorname{Pt}(1)-\mathrm{Br}(1)$ & $91.83(17)$ & $\operatorname{Br}(1)-\operatorname{Pt}(1)-\operatorname{Br}(2)$ & $177.088(19)$ \\
\hline \multicolumn{4}{|l|}{ Compound 2} \\
\hline \multicolumn{4}{|l|}{ Distances } \\
\hline $\operatorname{Pt}(1)-\mathrm{N}(1)$ & $2.055(4)$ & $\operatorname{Pt}(1)-\operatorname{Br}(1)$ & $2.4316(5)$ \\
\hline $\operatorname{Pt}(1)-\operatorname{Br}(2)$ & $2.4082(6)$ & $\operatorname{Pt}(1)-\operatorname{Br}(1) \# 1$ & $2.4479(5)$ \\
\hline \multicolumn{4}{|l|}{ Angles } \\
\hline $\mathrm{N}(1)-\mathrm{Pt}(1)-\mathrm{Br}(2)$ & $92.76(12)$ & $\operatorname{Br}(2)-\operatorname{Pt}(1)-\operatorname{Br}(1) \# 1$ & $91.004(18)$ \\
\hline $\mathrm{N}(1)-\operatorname{Pt}(1)-\mathrm{Br}(1)$ & $90.02(12)$ & $\operatorname{Br}(1)-\operatorname{Pt}(1)-\operatorname{Br}(1) \# 1$ & $86.233(17)$ \\
\hline $\operatorname{Br}(2)-\operatorname{Pt}(1)-\operatorname{Br}(1)$ & $177.016(17)$ & $\operatorname{Pt}(1)-\operatorname{Br}(1)-\operatorname{Pt}(1) \# 1$ & $93.767(17)$ \\
\hline $\mathrm{N}(1)-\operatorname{Pt}(1)-\mathrm{Br}(1) \# 1$ & $176.19(12)$ & & \\
\hline
\end{tabular}

Symmetry transformations used to generate equivalent atoms: \#1 -x,-y,-z+1 


\section{Results and Discussion}

\section{(a) Synthesis and characterisation of the starting materials.}

The synthetic work is summarized in Scheme 2. Complex trans- $\mathrm{PtBr}_{2}\left(\mathrm{C}_{2} \mathrm{H}_{4}\right)\left(\mathrm{HNEt}_{2}\right)$ (1) was synthesized in 75\% yield starting from Zeise's salt by adapting the methodology previously described for the preparation of related complex trans- $\mathrm{PtBr}_{2}\left(\mathrm{C}_{2} \mathrm{H}_{4}\right)\left(\mathrm{PhNH}_{2}\right), \mathbf{1 a}$ [7].

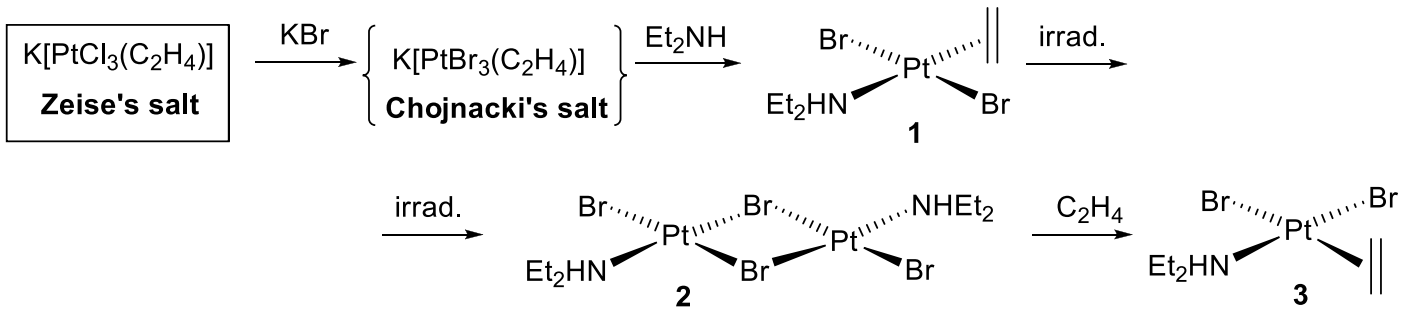

\section{Scheme 2}

The trans square planar coordination geometry of $\mathbf{1}$ was confirmed by a single crystal X-ray structural study, see Figure 1, which reveals a short contact between the N-H proton and one of the $\mathrm{Br}$ atoms $(\mathrm{Br} 1 \cdots \mathrm{H}-\mathrm{N} 1=2.71 \AA)$. The solution ${ }^{1} \mathrm{H}$ NMR spectrum is consistent with the solid state geometry, with two independent resonances as complex multiplets at $\delta 3.36$ and 3.13 for the diastereotopic methylene protons. One pair of these protons also shows ${ }^{195} \mathrm{Pt}$ satellites $(\mathrm{J}=66 \mathrm{~Hz}$, see Figure $\mathrm{S} 1)$. The equivalent $\mathrm{CH}_{3}$ protons show a complex signal the shape of which approaches a first-order binomial triplet at $\delta$ $1.53(500 \mathrm{MHz}$, Figure S1), while it is more complex at $300 \mathrm{MHz}$ (Figure S2). The broad amine $\mathrm{NH}$ proton $(\delta$ ca. 5.6) also shows coupling with the Pt nucleus (ca. $90 \mathrm{~Hz}$ ). 


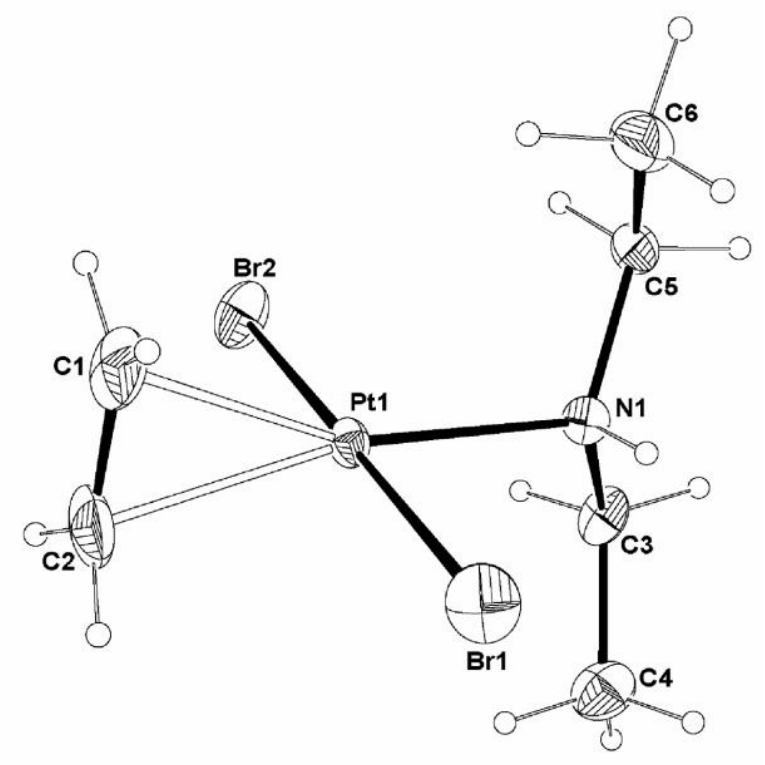

Figure 1. An ORTEP view of the molecular structure of trans- $\mathrm{PtBr}_{2}\left(\mathrm{C}_{2} \mathrm{H}_{4}\right)\left(\mathrm{NHEt}_{2}\right), \mathbf{1}$ The thermal ellipsoids are drawn at the $50 \%$ probability level.

The ${ }^{195} \mathrm{Pt}\left\{{ }^{1} \mathrm{H}\right\}$ NMR resonance of $\mathbf{1}$ is peculiar, see Figure 2. It shows as a 1:1:1 triplet, the shape of which is distorted to yield approximate relative heights of 1:1.7:1 at 64.2 $\mathrm{MHz}$ and $1: 1.25: 1$ at $107.2 \mathrm{MHz}(\mathrm{J}=218 \mathrm{~Hz})$. The observed coupling, which is attributed to the quadrupolar ${ }^{14} \mathrm{~N}$ atom $(\mathrm{I}=1)$, is not usually observed in the ${ }^{195} \mathrm{Pt} \mathrm{NMR}$ spectrum of platinum amine compounds [37], but the resonance shape and relative signal intensities are well understood [38]. Other rare examples of this phenomenon have been reported for the ammonia complexes $\left[\mathrm{Pt}\left(\mathrm{NH}_{3}\right)_{4}\right]^{2+},\left[\text { cis- } \mathrm{Pt}\left(\mathrm{NH}_{3}\right)_{2}\left(\mathrm{H}_{2} \mathrm{O}\right)_{2}\right]^{2+}$ [39] and $\mathrm{K}\left[\mathrm{Pt}\left(\mathrm{NH}_{3}\right) \mathrm{Cl}_{3}\right][40]$.

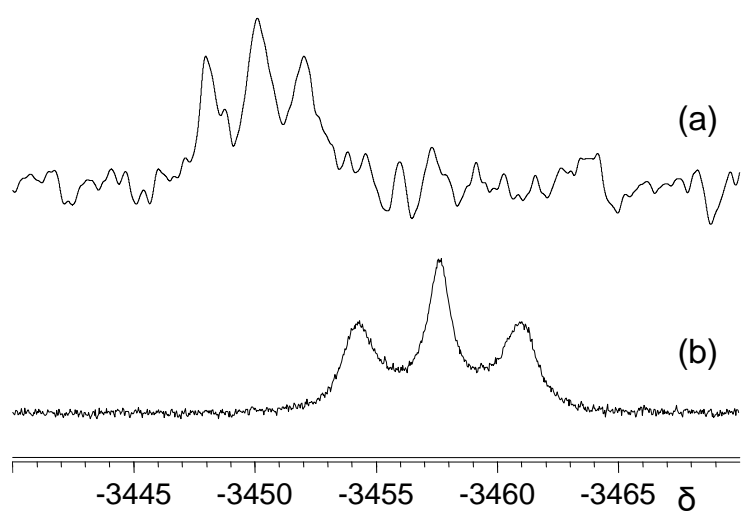

Figure 2. ${ }^{195} \mathrm{Pt}\left\{{ }^{1} \mathrm{H}\right\}$ NMR of $\mathbf{1}$ in acetone- $d_{6}$ at 107.2 MHz (a) and 64.2 MHz (b). 
While the synthesis of $\mathbf{1}$ is relatively straightforward, that of its cis isomer $\mathbf{3}$ is more problematic. The same methodology adopted for the preparation of cis$\mathrm{PtBr}_{2}\left(\mathrm{C}_{2} \mathrm{H}_{4}\right)\left(\mathrm{PhNH}_{2}\right)$ [7] (ethylene addition to the aminetribromoplatinate precursor) cannot be applied here because the product cannot be kinetically stabilized by precipitation and thus led again to the thermodynamically preferred $\mathbf{1}$ as a sole product under these conditions. An alternative synthetic pathway, described for a related $\mathrm{Cl}-\mathrm{NHMe}_{2}$ complex [13, 41], involves the irradiation of trans- $\mathrm{PtCl}_{2}\left(\mathrm{C}_{2} \mathrm{H}_{4}\right)\left(\mathrm{HNMe}_{2}\right)$ to afford trans$\mathrm{Pt}_{2} \mathrm{Cl}_{4}\left(\mathrm{HNMe}_{2}\right)_{2}$, from which cis- $\mathrm{PtCl}_{2}\left(\mathrm{C}_{2} \mathrm{H}_{4}\right)\left(\mathrm{HNMe}_{2}\right)$ is obtained by addition of ethylene. This procedure indeed led to the formation of the desired complex $\mathbf{3}$, although less efficiently because the ethylene addition to the intermediate dinuclear complex $\mathbf{2}$ is extremely slow (more than 4 days $v s .2-4 \mathrm{~h}$ for the $\mathrm{Cl}$ analogue). The intermediate 2 was also obtained more slowly than the Cl-NHMe 2 analogue under the same conditions (18vs. 12 h). The molecular structure of complex 2 was also obtained, see Figure 3.

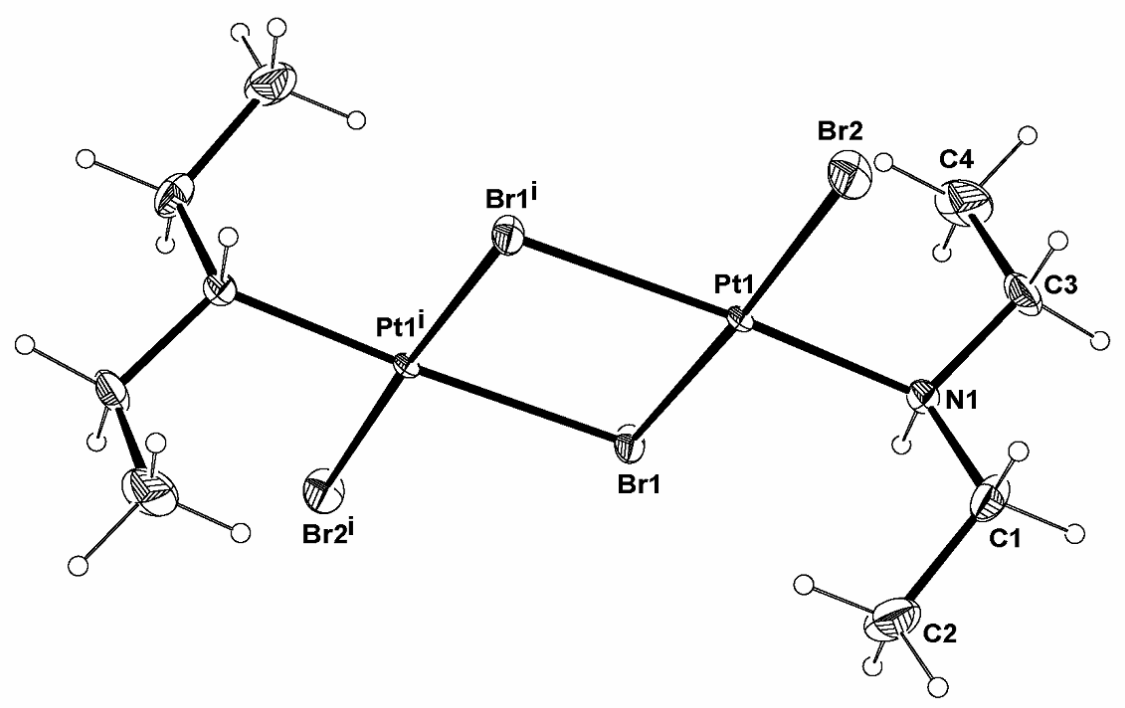

Figure 3. An ORTEP view of the molecular structure of trans-[ $\left.\mathrm{PtBr}_{2}\left(\mathrm{NHEt}_{2}\right)\right]_{2}, 2$. The thermal ellipsoids are drawn at the 50\% probability level. Symmetry code: (i) x, -y, 1-z. 
Like complex $\mathbf{1}$, complex 3 also shows ${ }^{195} \mathrm{Pt}^{-14} \mathrm{~N}$ coupling $\left({ }^{1} \mathrm{~J}=213 \mathrm{~Hz}\right)$ in the ${ }^{195} \mathrm{Pt}\left\{{ }^{1} \mathrm{H}\right\}$ spectrum. It does not show, on the other hand, ${ }^{195} \mathrm{Pt}$ satellites for the broad $\mathrm{C}_{2} \mathrm{H}_{4}$ ligand resonance in the ${ }^{1} \mathrm{H}$ NMR spectrum. Since the yield of $\mathbf{3}$ is very small, we shall only concentrate on the reaction between $\mathrm{HNEt}_{2}$ and the trans isomer $\mathbf{1}$ for the model study of the nucleophilic attack to coordinated ethylene, relevant to the Pt-catalyzed ethylene hydroamination mechanism.

\section{(b) Reaction between trans-PtBr $2\left(\mathrm{C}_{2} \mathrm{H}_{4}\right)\left(\mathrm{HNEt}_{2}\right)$ and $\mathrm{HNEt}_{2}$ in dichloromethane.}

The addition of $\mathrm{NHEt}_{2}$ to $\mathbf{1}$ in $\mathrm{CD}_{2} \mathrm{Cl}_{2}$ at $298 \mathrm{~K}$ was followed by ${ }^{1} \mathrm{H},{ }^{13} \mathrm{C}\left\{{ }^{1} \mathrm{H}\right\}$ and ${ }^{195} \mathrm{Pt}\left\{{ }^{1} \mathrm{H}\right\}$ NMR, giving evidence for the equilibrated formation, within time of mixing, of the zwitterionic complex trans $-\mathrm{Pt}^{(-)} \mathrm{Br}_{2}\left(\mathrm{NHEt}_{2}\right)\left(\mathrm{CH}_{2} \mathrm{CH}_{2} \mathrm{~N}^{(+)} \mathrm{HEt}_{2}\right)$ (4), according to Scheme 3. At long reaction times (2-3 days), the deposition of black particles (presumably $\mathrm{Pt}^{0}$ ) occurred, but the solution was relatively stable over the first few hours for a full NMR investigation to be carried out. Only the spectra run in $\mathrm{CD}_{2} \mathrm{Cl}_{2}$ under argon are shown in the figures and discussed in detail; similar results were also obtained in $\mathrm{CDCl}_{3}$ or in air.

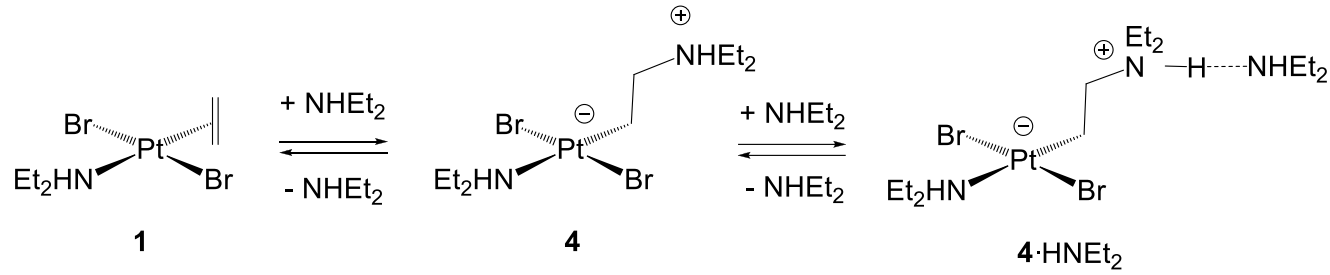

Scheme 3

The transformation of $\mathbf{1}$ to $\mathbf{4}$ is indicated by the decrease of the ${ }^{1} \mathrm{H}$ NMR $\mathrm{C}_{2} \mathrm{H}_{4}$ resonance at $\delta 4.77$ in favour of the two methylene triplet resonances of the ethylene chain in the $\mathrm{CH}_{2} \mathrm{CH}_{2} \mathrm{~N}^{(+)} \mathrm{HEt}_{2}$ ligand at ca. $\delta 2.86\left(J_{\mathrm{H}-\mathrm{Pt}}=32 \mathrm{~Hz}\right)$ and $2.09\left(J_{\mathrm{H}-\mathrm{Pt}}=94 \mathrm{~Hz}\right)$, see Figure S3. Integration of the residual $\mathrm{C}_{2} \mathrm{H}_{4}$ resonance of $\mathbf{1}$ demonstrates its persistence 
even in the presence of amine excess (up to at least 3 equiv). Simultaneously, the added amine in the same ligand shows two methylene multiplet resonances at $\delta 3.37$ and 3.21 for the diastereotopic protons. The coordinated amine equally shows a new pair of multiplet resonances for the diastereotopic methylene protons at $\delta$ ca. 3.08 and ca. 2.79 and the methyl triplet at $\delta 1.40$ (overlapping with the resonance of the ammonium group), while the NH proton is shifted to $\delta$ ca. 7.9 with observable Pt satellites $\left(\mathrm{J}_{\mathrm{Pt}-\mathrm{H}}=\mathrm{ca} .90 \mathrm{~Hz}\right)$. The $\mathrm{NH}$ protons of the $\mathrm{CH}_{2} \mathrm{CH}_{2} \mathrm{~N}^{(+)} \mathrm{HEt}_{2}$ ligand and of the excess free $\mathrm{NHEt}_{2}$, on the other hand, are not visible, probably because they are broadened beyond detection. On the other hand, all these $\mathrm{NH}$ protons must be exchanging rather slowly (the $\mathrm{N}$ atom inversion is very slow), as suggested by the observation of separate resonances for the diastereotopic methylene protons. As will be shown in the next section, the behaviour in acetone- $d_{6}$ is different. The full assignment of the resonances of $\mathbf{4}$ is shown in Figure 4. 


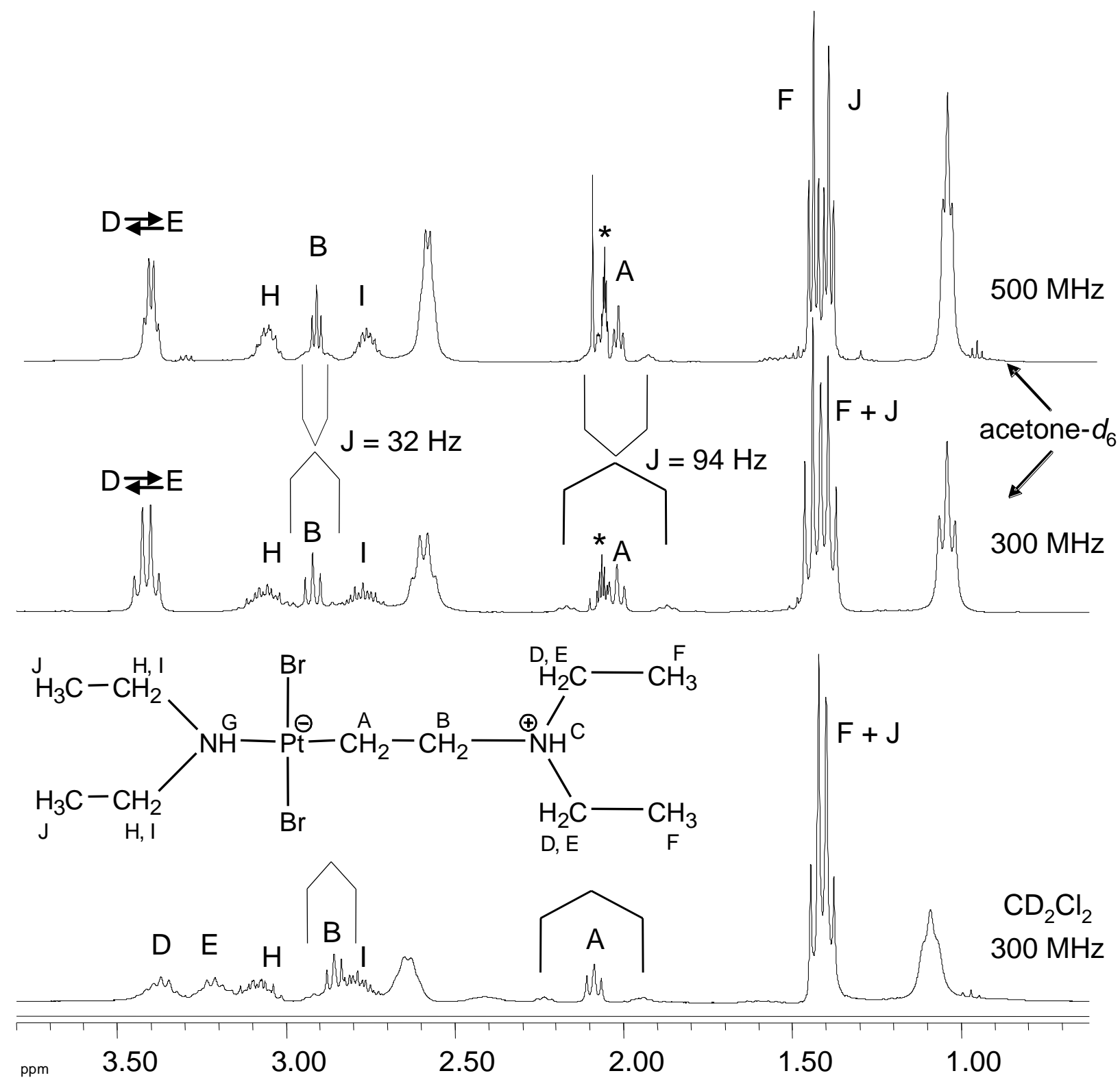

Figure 4. Selected region of the ${ }^{1} \mathrm{H}$ NMR spectra for compound 4 in the presence of 2 equiv $\mathrm{NHEt}_{2}$ at $298 \mathrm{~K}$, with resonance assignments. The resonances at $\delta$ ca. 2.6 (quartet) and 1.1 (triplet) are due to excess NHEt $_{2}$. The asterisk for the spectra in acetone- $d_{6}$ indicates the solvent resonance.

The aliphatic proton resonances of the free $\mathrm{NHEt}_{2}$ are broad when small amounts are present; they sharpen and shift to approach the pure $\mathrm{NHEt}_{2}$ values in the presence of larger amounts. The resonances of the coordinated $\mathrm{NHEt}_{2}$ and $\mathrm{CH}_{2} \mathrm{CH}_{2} \mathrm{~N}^{(+)} \mathrm{HEt}_{2}$ ligands in 4 do not show any unusual broadening as a function of the $\mathrm{NHEt}_{2} / \mathrm{Pt}$ excess, indicating that these ligands are not involved in any rapid dynamic process on the NMR time scale. The 
coordinated $\mathrm{NHEt}_{2}$ resonances in residual 1, on the other hand, slightly broaden but do not significantly shift in the presence of free $\mathrm{NHEt}_{2}$ (see Figure S3), suggesting a slow $\mathrm{NHEt}_{2}$ self-exchange process (close to the slow exchange limit in NMR) for compound $\mathbf{1}$. This is much slower than for the related complex trans- $\mathrm{PtBr}_{2}\left(\mathrm{C}_{2} \mathrm{H}_{4}\right)\left(\mathrm{PhNH}_{2}\right)$, for which a single resonance for coordinated and free $\mathrm{PhNH}_{2}$ was observed (fast exchange limit in NMR) [7]. Therefore, the shift and broadening of the free $\mathrm{Et}_{2} \mathrm{NH}$ resonances cannot be caused by any chemical exchange within compounds 1 and 4. We propose that it results from a rapid exchange between the excess free and $\mathrm{H}$-bonded amine in a $\mathbf{4} \cdot \mathrm{HNEt}_{2}$ adduct, see Scheme 3. The formation of H-bonded interactions by amines coordinated to platinum complexes is precedented.[42-44]

The conversion of $\mathbf{1}$ to $\mathbf{4}$ is accompanied by the generation of a major resonance at $\delta$ -3565 in the ${ }^{195} \mathrm{Pt}\left\{{ }^{1} \mathrm{H}\right\}$ NMR spectrum (Figure S4) and resonances at $\delta-13.6\left({ }^{1} J_{\mathrm{C}-\mathrm{Pt}}=667\right.$ $\mathrm{Hz})$ and $60.7\left({ }^{2} J_{\mathrm{C}-\mathrm{Pt}}=36 \mathrm{~Hz}\right)$ for the $\alpha$ and $\beta \mathrm{C}$ atoms of the $\mathrm{CH}_{2} \mathrm{CH}_{2} \mathrm{~N}^{(+)} \mathrm{HEt}_{2}$ ligand in the ${ }^{13} \mathrm{C}\left\{{ }^{1} \mathrm{H}\right\}$ NMR spectrum (Figure S5). The $\mathrm{NHEt}_{2}{ }^{13} \mathrm{C}$ resonances of residual $\mathbf{1}$ are broadened by free $\mathrm{NHEt}_{2}$, whereas those of the same ligand in $\mathbf{4}$ remain sharp, confirming the ${ }^{1} \mathrm{H}$ NMR evidence for the amine exchange dynamics. Time evolution of these spectra shows the formation of decomposition products more clearly than the ${ }^{1} \mathrm{H}$ spectrum, given the reduced number of resonances and their greater spread.

The amine addition reaction was also monitored by IR spectroscopy. Compound $\mathbf{1}$ exhibits a $v_{\mathrm{NH}}$ band at $3227 \mathrm{~cm}^{-1}\left(\varepsilon=100 \mathrm{M}^{-1} \mathrm{~cm}^{-1}\right)$ for the coordinated $\mathrm{Et}_{2} \mathrm{NH}$ ligand in $\mathrm{CH}_{2} \mathrm{Cl}_{2}$. Upon addition of an increasing amount of $\mathrm{Et}_{2} \mathrm{NH}$ this band decreases in favor of a new band at $3248 \mathrm{~cm}^{-1}\left(\varepsilon=37 \mathrm{M}^{-1} \mathrm{~cm}^{-1}\right)$, which is attributed to the $\mathrm{NHEt}_{2}$ ligand of compound 4 (see Figure S6). The shift of this band to higher frequency on going from $\mathbf{1}$ to 4 is in agreement with predictions based on DFT calculations (vide infra). A variable temperature study on the solution containing 1 equiv of $\mathrm{NHEt}_{2}$ (Figure S7) shows an equilibrium shift toward $\mathbf{4}$ upon cooling, evidencing exothermicity for the amine addition 
process. Quantitative analysis of the acquired data indicated a 1:1 reaction stoichiometry (Figure S8) with thermodynamic parameters $\Delta \mathrm{H}^{\circ}=-6.8 \pm 0.5 \mathrm{kcal} / \mathrm{mol}$ and $\Delta \mathrm{S}^{\circ}=-14.0 \pm$ 2.0 e.u. (Figure S9). These values correspond to $\mathrm{K}_{298 \mathrm{~K}}=80 \mathrm{M}^{-1}$ and $\Delta \mathrm{G}_{298 \mathrm{~K}}=-2.6$ $\mathrm{kcal} / \mathrm{mol}$. A related parameter for the addition of $\mathrm{HNEt}_{2}$ to trans $-\mathrm{PtCl}_{2}\left(\mathrm{C}_{2} \mathrm{H}_{4}\right)\left(\mathrm{HNEt}_{2}\right)$, investigated by NMR spectroscopy in chloroform, gave values of $\mathrm{K}_{298 \mathrm{~K}}=12 \mathrm{M}^{-1}\left(\Delta \mathrm{G}_{298 \mathrm{~K}}\right.$ $=-1.5 \mathrm{kcal} / \mathrm{mol})[19]$.

Analysis of the spectra below $3000 \mathrm{~cm}^{-1}$ (Figure S10) did not reveal bands that could be clearly attributable to the ammonium $\mathrm{NH}$ vibration, but showed the disappearance of the bands of 1 (at 1326, $1218 \mathrm{~cm}^{-1}$ ) and $\operatorname{Et}_{2} \mathrm{NH}\left(1327,1184,1140,1125 \mathrm{~cm}^{-1}\right)$ and the appearance of several new bands attributed to 4 (at 1395, 1354, 1342, 1206, 1089, 1026 $\mathrm{cm}^{-1}$ ) and assigned to numerous deformational $\mathrm{N}-\mathrm{H}$ vibrations of the $\mathrm{Et}_{2} \mathrm{NH}$ and $-\mathrm{CH}_{2} \mathrm{CH}_{2} \mathrm{~N}^{(+)} \mathrm{HEt}_{2}$ ligands, mixed with $\mathrm{CH}$ deformations. Notably, these bands increase in a similar manner both upon the $\mathrm{Et}_{2} \mathrm{NH}$ excess increase and upon temperature decrease. There was no indication of new species generated by a higher amine excess, in agreement with the NMR results described above.

The absence of observable bands due to the ammonium NH vibration may result from strong intra- and intermolecular associations in $\mathbf{4}$ and $\mathbf{4} \cdot \mathrm{NHEt}_{2}$, respectively. As generally appreciated, H-bonding has the effect of broadening the $\mathrm{N}-\mathrm{H}$ vibration and shifting it toward lower frequency. In order to further confirm this hypothesis, an IR investigation in $\mathrm{CH}_{2} \mathrm{Cl}_{2}$ was also carried out for the protonation of $\mathrm{Et}_{3} \mathrm{~N}$ by $\mathrm{CF}_{3} \mathrm{COOH}$, yielding $\mathrm{Et}_{3} \mathrm{NH}^{+}$as a model of the putative $-\mathrm{CH}_{2} \mathrm{CH}_{2} \mathrm{~N}^{(+)} \mathrm{HEt}_{2}$ unit in 4 (Figure $\mathrm{S} 11$ ). It did not reveal a $v_{\mathrm{NH}}$ band attributable to $\mathrm{Et}_{3} \mathrm{NH}^{+}$, although the formation of ionic species is evident from the presence of the $\mathrm{CF}_{3} \mathrm{COO}^{-}$anion $v^{\text {as }}$ Oco band at $1673 \mathrm{~cm}^{-1}$ [45]. Hence, this experiment justifies the lack of observation of a spectroscopic signature for the ammonium ion of 4 in the IR spectrum. 


\section{(c) Reaction between trans-PtBr2 $2\left(\mathrm{C}_{2} \mathrm{H}_{4}\right)\left(\mathrm{HNEt}_{2}\right)$ and $\mathrm{HNEt}_{2}$ in acetone.}

The same experiment described above was also carried out in acetone. The reason for this choice is that acetone is more polar than dichloromethane $(\varepsilon=20.49$ vs. 8.93 for $\mathrm{CH}_{2} \mathrm{Cl}_{2}$ ) and may therefore favour the formation of charge-separated species, for instance deprotonation of the zwitterion $\mathbf{4}$ by excess $\mathrm{NHEt}_{2}$ to yield a negatively charged aminoethyl $\mathrm{Pt}^{\mathrm{II}}$ complex and $\mathrm{Et}_{2} \mathrm{NH}_{2}{ }^{+}$. The results of the NMR and IR investigations were very similar to those described above in dichloromethane within the first few hours from mixing, again in agreement with the transformations outlined in Scheme 3. Identical results were also observed working under an argon atmosphere or in air. The relevant results of the ${ }^{1} \mathrm{H},{ }^{195} \mathrm{Pt}\left\{{ }^{1} \mathrm{H}\right\}$ and ${ }^{13} \mathrm{C}\left\{{ }^{1} \mathrm{H}\right\}$ monitoring are shown in Figures S12-14. An interesting difference concerns the dynamic behaviour. As clearly shown in Figure 4, the diastereotropic methylene protons of the ammonium ethyl groups are collapsed into a single quartet resonance in this solvent. This phenomenon is attributed to a faster deprotonation/amine inversion/reprotonation via the $\mathbf{4} \cdot \mathrm{NHEt}_{2}$ intermediate, which is favoured by the higher dielectric constant of the acetone medium. This point will be addressed again in the computational part below. The ${ }^{1} \mathrm{H}$ NMR spectra show the same shifting of the excess free $\mathrm{NHEt}_{2}$ resonances, confirming rapid $\mathbf{4} / \mathbf{4} \cdot \mathrm{NHEt}_{2}$ exchange, and the broadening of the coordinated $\mathrm{NHEt}_{2}$ resonance in residual 1, indicating slow selfexchange, as also observed in $\mathrm{CD}_{2} \mathrm{Cl}_{2}$ (vide supra).

The immediate, selective and equilibrated formation of compound 4 in acetone- $d_{6}$ was again confirmed by the ${ }^{195} \mathrm{Pt}\left\{{ }^{1} \mathrm{H}\right\}$ and ${ }^{13} \mathrm{C}\left\{{ }^{1} \mathrm{H}\right\}$ NMR monitoring. The former shows a singlet resonance at $\delta-3550$ while the latter reveals the characteristic $\mathrm{Pt}-\mathrm{C}(\alpha)-\mathrm{C}(\beta)$ resonances with $\mathrm{Pt}$ satellites at $\delta-14.7\left({ }^{1} J_{\mathrm{C}-\mathrm{Pt}}=667 \mathrm{~Hz}\right)$ and $\delta 59.5\left({ }^{2} J_{\mathrm{C}-\mathrm{Pt}}=36 \mathrm{~Hz}\right)$, respectively (Figures S13 and S14). These chemical shifts correspond closely to those observed in $\mathrm{CD}_{2} \mathrm{Cl}_{2}$ (vide supra). The decomposition occurred at a faster rate in acetone and led to different products relative to dichloromethane. The investigation of the nature of 
these decomposition products was not further pursued. The deposition of black solid occurred in both solvents after a few days and no formation of $\mathrm{NEt}_{3}$ was observed during the decomposition.

Addition of the strong acid $\mathrm{CF}_{3} \mathrm{SO}_{3} \mathrm{H}$ to a partially decomposed solution did not eliminate the resonances of the decomposition products (as monitored by ${ }^{13} \mathrm{C}\left\{{ }^{1} \mathrm{H}\right\} \mathrm{NMR}$ ), indicating that these are not produced by equilibrium processes involving the deprotonation of the zwitterion ammonium function by the excess $\mathrm{Et}_{2} \mathrm{NH}$. In a separate experiment, excess acid was added immediately to a solution of $\mathbf{4}$ generated in situ from $\mathbf{1}$ and 5 equiv of $\mathrm{Et}_{2} \mathrm{NH}$. The resonances of $\mathbf{4}$ disappeared, accompanied by the reappearance of the resonances of compound $\mathbf{1}$. This can be easily explained by the equilibrated nature of the nucleophilic amine addition to 1 to yield 4 (Scheme 3). In a separate experiment, two equivalent solutions of 1 in acetone- $d_{6}$ were treated, one with 6 equiv of $\mathrm{Et}_{2} \mathrm{NH}$, the other one with 8 equiv of $\mathrm{Et}_{2} \mathrm{NH}$ and then immediately with 2 equiv of $\mathrm{TfOH}$ (aiming at the in situ generation of 6 equiv of $\mathrm{Et}_{2} \mathrm{NH}$ and 2 equiv of $\mathrm{Et}_{2} \mathrm{NH}_{2}{ }^{+}$). The underlying idea was to verify whether the presence of the conjugate acid would retard the decomposition of 4, thus helping to rationalize the greater catalytic activity of $\mathrm{PtBr}_{2} / \mathrm{Br}^{-}$in the ethylene hydroamination by aniline when a small amount of a strong acid was added. The results (shown in the supplemental figures S15 and S16) reveal that the evolution of compound 4 is essentially the same in both cases. However, an important difference is observed immediately: a new set of resonances (a triplet and a quartet) for an ethyl derivative is seen in the spectrum following the addition of $\mathrm{TfOH}$. A spiking test confirmed the identity of this compound as $\mathrm{Et}_{3} \mathrm{~N}$ (0.38 equiv relative to $\mathrm{Pt}$, according to integration), as well as its absence in the experiment run without acid. Thus, it seems that the $\mathrm{Pt}-\mathrm{C}$ bond protonolysis and the protonation of the excess amine by $\mathrm{TfOH}$ are competitive, even though the amine is present in much larger amount ( 8 equiv per Pt complex). After this initial burst of protonolysis, no additional $\mathrm{Et}_{3} \mathrm{~N}$ is generated (its relative amount remains constant) while 
the residual 4 further decomposes, as it does in the absence of conjugate acid. This shows also that $\mathrm{Et}_{2} \mathrm{NH}_{2}{ }^{+}$, once formed, is not sufficiently acidic to induce the release of $\mathrm{Et}_{3} \mathrm{~N}$ from 4 or from any of the complexes generated by the decomposition of 4 .

As mentioned above, earlier reports have already shown the stoichiometric liberation of the hydroamination products from zwitterionic compounds [46-48], although these studies were carried out, to the best of our knowledge, on isolated compounds and under conditions where the equilibration with the starting olefin complex is not established (addition of a mineral solution of the strong acid to the isolated solid under heterogeneous conditions). Our observations on the protonation of the equilibrated solution show that, although the free amine is protonated, shifting the equilibrium back toward the olefin complex, protonation of the alkyl ligand leading to the hydroamination product also occurs, indicating that this process is faster than the equilibration between $\mathbf{1}$ and $\mathbf{4}$ (and even competitive with the protonation of the excess free $\mathrm{NHEt}_{2}$ ).

The IR monitoring of the amine addition in acetone yields a spectral picture in the $v_{\mathrm{NH}}$ region qualitatively identical to that in dichloromethane (Figure S17), except that the $v_{\mathrm{NH}}(\mathbf{1})$ band shows widening $\left(\Delta v_{1 / 2}=25 \mathrm{~cm}^{-1}\right.$ in acetone $v s$. only $10 \mathrm{~cm}^{-1}$ in dichloromethane) and low frequency asymmetry. This is probably due to the specific solvation effects $\left(\mathrm{NH} \cdots \mathrm{O}=\mathrm{CMe}_{2}\right.$ interaction). A quantitative analysis gives $\mathrm{K}_{298 \mathrm{~K}}=135$ $\mathrm{M}^{-1}\left(\Delta \mathrm{G}_{298 \mathrm{~K}}=-2.9 \mathrm{kcal} / \mathrm{mol}\right)$ for the nucleophilic addition equilibrium constant, slightly higher than the value in dichloromethane. Careful examination of all spectral changes (including down to $1000 \mathrm{~cm}^{-1}$ ) does not show any evidence for the presence of other species; however, the bands are wide and a large portion of the spectra is masked by the solvent absorptions.

\section{(d) Computational investigation.}


In a previous contribution [7] we have shown that the reaction of trans$\mathrm{PtBr}_{2}\left(\mathrm{C}_{2} \mathrm{H}_{4}\right)\left(\mathrm{PhNH}_{2}\right)$ (1a) with $\mathrm{PhNH}_{2}$ does not yield an observable zwitterionic product up to ca. $68^{\circ} \mathrm{C}$, the only observable process being a self-exchange of free and coordinated aniline molecules. In combination with a computational investigation [10], the lack of observation of the nucleophilic addition product was attributed to its high relative energy. On the other hand, we have shown in this contribution that the reaction between $\mathbf{1}$ and HNEt $_{2}$ gives observable equilibrium amounts of the zwitterionic product 4 and its $\mathrm{H}$ bonded derivative $4 \cdot \mathrm{NHEt}_{2}$ (Scheme 3 ). Hence, the reaction free energy associated to the nucleophilic amine addition must be smaller in this case. We have carried out a full QM DFT study on the conversion of $\mathbf{1}$ to $\mathbf{4}$ using the same computational level and approximations previously reported for the corresponding aniline system [10], without molecular simplification and with inclusion of the solvent effects through the C-PCM model, the only difference being the nature of the solvent (dichloromethane, $\varepsilon=8.93$, or acetone, $\varepsilon=20.49$ ) in the present study). It was shown for the aniline system that the most favourable nucleophilic addition pathway involves the amine attack to the olefin anti face relative to the metal, thus we restricted our calculations to this pathway also for the $\mathrm{NHEt}_{2}$ addition. Figure 5 summarizes the comparative results for the two systems.

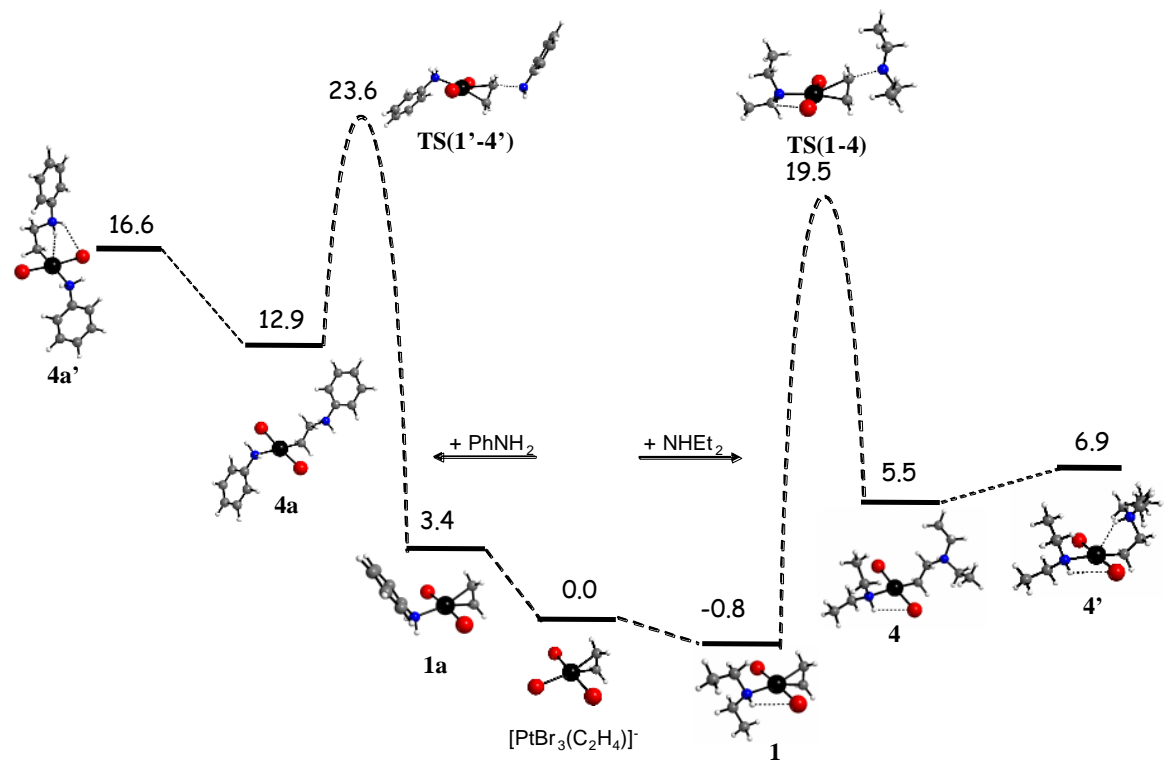


Figure 5. $\Delta \mathrm{G}^{\mathrm{C}-\mathrm{PCM}}$ in $\mathrm{kcal} \mathrm{mol}^{-1}$ at $298.15 \mathrm{~K}$ and views of the optimized geometries for the reagents, products and highest points along the amine nucleophilic addition pathway for compounds $\mathbf{1}$ and 1a, starting from the common precursor $\left[\mathrm{PtBr}_{3}\left(\mathrm{C}_{2} \mathrm{H}_{4}\right)\right]^{-}$.

The numbering scheme used for the $\mathrm{PhNH}_{2}$ system is the same as for the $\mathrm{NHEt}_{2}$ system with an added "a" suffix. All reported energies corresponds to $\Delta \mathrm{G}^{\mathrm{CPCM}}=\Delta \mathrm{G}_{\mathrm{gas}}+$ $\Delta \Delta \mathrm{G}_{\text {solv }}\left(\Delta \mathrm{G}_{\text {gas }}\right.$ is the free energy change of the reaction in the gas phase and $\Delta \mathrm{G}_{\text {solv }}$ is the free energy of solvation for each compound), which was found to provide the best qualitative agreement with the experimental results, in spite of the inevitable uncertainty associated with the calculation of the solvation entropy [21]. The $\Delta \mathrm{G}^{\mathrm{CPCM}}$ values are given relative to the common precursor $\left[\mathrm{PtBr}_{3}\left(\mathrm{C}_{2} \mathrm{H}_{4}\right)\right]^{-}$, taking into account the values of all species that are added to or subtracted from the system. This ion was indeed shown to be thermodynamically more stable than 1a by NMR investigations in $\mathrm{CD}_{2} \mathrm{Cl}_{2}$ solution and computational work indicated that it is the resting state of the $\mathrm{PtBr}_{2} / \mathrm{Br}^{-}$-catalyzed ethylene hydroamination by aniline [10].

The first notable observation from Figure 5 is that $\mathrm{NHEt}_{2}$ binds the metal atom more strongly than $\mathrm{PhNH}_{2}$, since the relative energy of $\mathbf{1}$ is $0.8 \mathrm{kcal} / \mathrm{mol}$ below that of $\left[\mathrm{PtBr}_{3}\left(\mathrm{C}_{2} \mathrm{H}_{4}\right)\right]^{-}$and $4.2 \mathrm{kcal} / \mathrm{mol}$ below that of $\mathbf{1 a}$. This result correlates at least qualitatively with the greater lability of the coordinated aniline, which undergoes selfexchange with free ligand in complex 1a considerably faster than the $\mathrm{NHEt}_{2}$ ligand in complex 1 (vide supra). The second interesting observation is that the nucleophilic addition barrier is essentially identical for both amines $(20.1 \mathrm{kcal} / \mathrm{mol}$ for $\mathbf{1 a}$ to $\mathbf{4 a}$ and 20.3 $\mathrm{kcal} / \mathrm{mol}$ for $\mathbf{1}$ to $\mathbf{4})$. The starting complexes have practically identical calculated $\mathrm{C}=\mathrm{C}$ distances (1.398 $\AA$ for $\mathbf{1}$ and $1.396 \AA$ for $\mathbf{1 a})$, indicating an essentially identical degree of $\pi$-back donation. The two transition states have also very similar geometries $(\mathrm{C} \cdots \mathrm{N}$ 
distance of ca. $2.0 \AA$ in both cases for the incipient bond) and charge distributions (Mulliken charges of -0.176 and -0.177 for the $C$ atom in $\mathbf{T S}(\mathbf{1 a - 4 a )}$ and TS(1-4), respectively). The optimized zwitterionic structures are nearly identical, except for the presence of an intramolecular $\mathrm{NH} \cdots \mathrm{Br}$ bond in $\mathbf{4}$ and its absence in $\mathbf{4 a}$. Both complexes are calculated as less stable than the precursor olefin complex, but the difference between 4 and 1 is $6.3 \mathrm{kcal} / \mathrm{mol}$ while that between $4 \mathbf{a}$ and $1 \mathbf{a}$ is greater, $9.5 \mathrm{kcal} / \mathrm{mol}$. The calculated free energy difference for the conversion of $\mathbf{1}$ to $\mathbf{4}$ is too large to be compatible with the observation of equilibrium between these two compounds. The computational error, given the amount of approximations related to the solvent model, inaccurate estimation of the solvation entropy, neglect of the counterion, in addition to the usual error related to the accuracy of the DFT method, are believed to be responsible for the discrepancy. However, the energy difference changes in the right direction on going from the aniline to the $\mathrm{NHEt}_{2}$ system. The calculated reaction enthalpy, including the solvation effects, is $-4.9 \mathrm{kcal} / \mathrm{mol}$, in rather good agreement with the experimentally determined value from the IR study (vide supra).

The optimized structure of the zwitterions $\mathbf{4}$ shows, like that previously reported for 4a, an anti conformation for the $\mathrm{CH}_{2} \mathrm{CH}_{2}$ chain linking the $\mathrm{Pt}$ atom and the ammonium function. We have also optimized an isomeric structure where the ammonium function establishes an intramolecular H-bond with the metal center (4', see Figure 5). Interest in this calculation stemmed from the fact that the analogue $\mathbf{4} \mathbf{a}^{\prime}$ for the $\mathrm{PhNH}_{2}$ system was shown to be an intermediate for the hydroamination catalysis, delivering a proton to the $\mathrm{Pt}$ center in one of the key steps of the catalytic cycle. Like for the $\mathrm{PhNH}_{2}$ system, this intramolecular $\mathrm{H}$-bonded isomer is found less stable than the non bonded version in terms of $\Delta \mathrm{G}^{\mathrm{C}-\mathrm{PCM}}$, although marginally favored in terms of $\Delta \mathrm{H}^{\mathrm{C}-\mathrm{PCM}}(-0.7 \mathrm{kcal} / \mathrm{mol})$, indicating that the enthalpic advantage of the $\mathrm{H}$-bond does not compensate the increased steric tension and the increased ordering associated with the eclipsed conformation of the carbon 
chain. An additional calculation was also carried out on the intermolecular H-bonded adduct $4 \cdot \mathrm{NHEt}_{2}$. This adduct is calculated as less stable on the free energy scale by 8.6 $\mathrm{kcal} / \mathrm{mole}$ in dichloromethane (Figure 6), but more stable by $-3.7 \mathrm{kcal} / \mathrm{mol}$ in terms of $\Delta \mathrm{H}^{\mathrm{C}-}$ $\mathrm{PCM}$. Hence, the hypothesis of the formation of equilibrium amounts of $4 \cdot \mathrm{NHEt}_{2}$ to rationalize the NMR behaviour of the excess free $\mathrm{NHEt}_{2}$ appears justified.

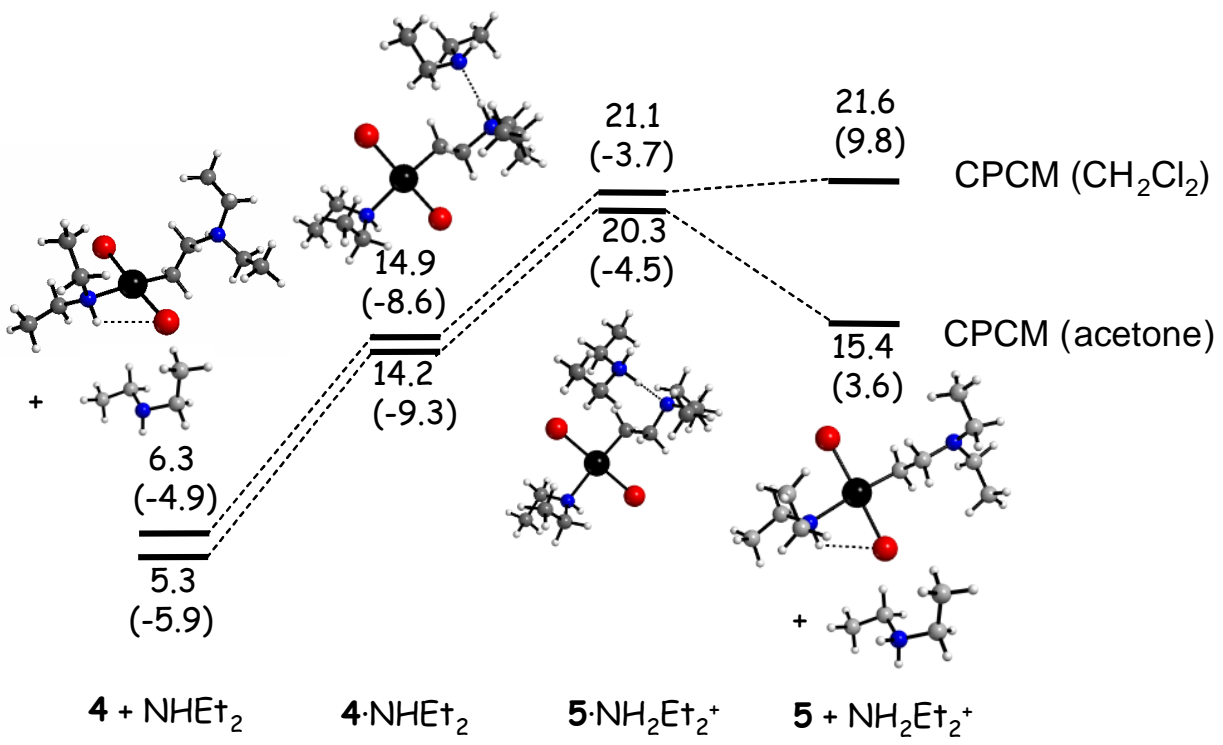

Figure 6. $\Delta \mathrm{G}^{\mathrm{C}-\mathrm{PCM}}$ (and $\Delta \mathrm{H}^{\mathrm{C}-\mathrm{PCM}}$ in parentheses) in $\mathrm{kcal} \mathrm{mol}^{-1}$ at $298.15 \mathrm{~K}$ relative to complex 1 and views of the optimized geometries for the proton transfer from 4 to $\mathrm{NHEt}_{2}$ in dichloromethane and in acetone.

We have also calculated the energy cost for transferring a proton from the ammonium function of 4 to the H-bonded amine, leading from $\mathbf{4} \cdot \mathrm{NHEt}_{2}$ to the aminoalkyl complex [(NHEt 2$\left.) \mathrm{Br}_{2} \mathrm{Pt}\left(\mathrm{CH}_{2} \mathrm{CH}_{2} \mathrm{NEt}_{2}\right)\right]^{-}$, 5, H-bonded with the corresponding counterion $\mathrm{Et}_{2} \mathrm{NH}_{2}{ }^{+}$, and for the subsequent charge-separated ions. Since this process, proposed as responsible for the equilibration of the methylene diastereotopic protons of the ammonium moiety, occurs at different rates in $\mathrm{CD}_{2} \mathrm{Cl}_{2}$ and acetone- $d_{6}$ (Figure 4), the calculations were carried out with the C-PCM in both solvents. The results, also reported in Figure 6, show that the proton transfer process is endoergic and requires approximately the same energy in both 
solvents. On the other hand, the separation of the charged species in the $\mathbf{5} \cdot \mathrm{NH}_{2} \mathrm{Et}_{2}{ }^{+}$ product is quite solvent-dependent, being slightly endoergic in dichloromethane and exoergic in acetone. When considering that the entropic part of the free energy is partially quenched in solution, the last step (charge separation) becomes the rate determining step. Thus, the more polar acetone solvent indeed seems to promote the easier equilibration of the diastereotopic methylene protons of the ammonium function via faster deprotonation and reprotonation after inversion of the pyramidal $\mathrm{N}$ atom.

Finally, we have also attempted to optimize a structure obtained by intramolecular proton transfer from the ammonium function to the $\mathrm{Pt}$ atom, namely a $\mathrm{Pt}^{\mathrm{IV}}$ hydrido complex of formula $\left[\mathrm{Pt}(\mathrm{H}) \mathrm{Br}_{2}\left(\mathrm{NHEt}_{2}\right)\left(\mathrm{CH}_{2} \mathrm{CH}_{2} \mathrm{NEt}_{2}\right)\right]$. A related complex was shown to be implicated as a catalytic intermediate in the ethylene hydroamination by aniline [10]. However, contrary to the aniline system a stable minimum for this complex was not obtained, leading back to the geometry of the zwitterion 4 instead, which may be rationalized by the greater basicity of the aminoalkyl ligand for the $\mathrm{Et}_{2} \mathrm{NH}$ system.

The frequency calculations have helped with the assignment of the IR spectral changes upon $\mathrm{NHEt}_{2}$ nucleophilic addition. The results are shown in the supplemental Table S1. The calculated values of the $v_{\mathrm{NH}}$ frequencies are ca. $200 \mathrm{~cm}^{-1}$ higher than the experimental values, but the blue shift of $+29 \mathrm{~cm}^{-1}$ for the coordinated $\mathrm{NHEt}_{2}$ on going from 1 to 4 corresponds closely to the experimentally observed shift of $+21 \mathrm{~cm}^{-1}$. According to the computation prediction, the $v_{\mathrm{NH}}$ frequency and intensity of the free ammonium function in $\mathbf{4}$ are similar to those of the coordinated NHEt $_{2}$ ligand, but the absorption greatly red-shifts and increases in intensity when the group is H-bonded in an intra- or intermolecular fashion. Since no absorptions are experimentally observed in the predicted regions of the IR spectrum, although the intermolecular bonding interaction is suggested by the NMR data, we suspect that the compound is indeed mostly present as H- 
bonded adduct $4 \cdot \mathrm{NHEt}_{2}$, the $v_{\mathrm{NH}}$ absorption of which is not visible given the expected broadening and the overlap with other absorptions.

\section{Conclusions}

The present study aimed at better understanding the $\mathrm{PtBr}_{2} / \mathrm{Br}^{-}$catalytic system, which is rather efficient for the hydroamination of ethylene [1, 7] and higher olefins $[4,5]$ by low-basicity amines [6], but is limited by catalyst decomposition with formation of inactive metallic platinum $[1,8]$. Greater activity was previously reported under anhydrous conditions in the presence of a small amount of a strong acid as co-catalyst [1]. On the basis of literature reports, the stability of $\mathrm{Pt}^{\mathrm{II}}\left(\mathrm{C}_{2} \mathrm{H}_{4}\right)$ complexes in the presence of amines seems dependent on deprotonation processes for the zwitterionic product of amine addition to the coordinated olefin to yield aminoalkyl ligands, which then may evolve in a number of ways and often lead to the deposition of metallic Pt $[13,16,18]$. Therefore, the role of the acid may well be that of protecting the zwitterionic intermediate against equilibrium deprotonation and subsequent decomposition.

With this concept in mind, we have investigated the addition of an amine of high basicity, $\mathrm{NHEt}_{2}$, capable of yielding observable amounts of the zwitterionic product, and used two different solvents of different polarity (dichloromethane and acetone). The choice of acetone, not frequently used in this type of investigation, was indeed guided by the consideration that its greater dielectric constant should favour the transfer of a proton to the excess of external $\mathrm{NHEt}_{2}$ and thus trigger faster decomposition. Indeed, the DFT calculations support the notion that deprotonation of the zwitterionic derivative 4 should occur more easily in acetone. Indeed, the compound decomposes faster in this solvent. No direct evidence for the formation of an aminoalkyl complex was obtained in our study. The

most relevant result, suggesting an easier deprotonation in acetone, is a faster dynamic 
process equalizing the resonances of diastereotopic methylene protons for the ammonium function. Catalytic hydroamination, on the other hand, apparently needs intramolecular proton transfer from the ammonium function of the zwitterion to the $\mathrm{Pt}$ atom or directly to the Pt-bonded $\mathrm{C}$ atom $[5,10]$. Hence, conditions limiting deprotonation should lead to greater catalyst stability and hence increase the turnover number. This proposition is now subject to further testing in catalytic intermolecular hydroamination.

\section{Acknowledgement}

We are grateful to the CNRS (Centre National de la Recherche Scientifique) and the RFBR (Russian Foundation for Basic Research) for support through the GDRI (Groupe de Recherche Internationale) "Homogeneous catalysis for Sustainable Development" and a France-Russia (RFBR - CNRS) bilateral grant № 08-03-92506. The French group also thanks the ANR (Agence Nationale de la Recherche, Grant No. NT09_442499) for additional financial support, as well as the CINES (Centre Informatique National de l'Enseignement Supérieur) and the CICT (Centre Interuniversitaire de Calcul de Toulouse, project CALMIP) for granting free computational time. PD thanks the MENESR (Ministère de l'Éducation Nationale, de l'Enseignement Supérieur et de la Recherche, France) for a Ph.D. fellowship. 


\section{References}

[1] J. J. Brunet, M. Cadena, N. C. Chu, O. Diallo, K. Jacob, E. Mothes, Organometallics 23 (2004) 1264-1268.

[2] X. Wang, R. A. Widenhoefer, Organometallics 23 (2004) 1649-1651.

[3] D. Karshtedt, A. T. Bell, T. D. Tilley, J. Am. Chem. Soc. 127 (2005) 12640-12646.

[4] J. J. Brunet, N. C. Chu, O. Diallo, Organometallics 24 (2005) 3104-3110.

[5] M. Rodriguez-Zubiri, S. Anguille, J.-J. Brunet, J. Mol. Catal. A 271 (2007) 145150.

[6] J.-J. Brunet, N.-C. Chu, M. Rodriguez-Zubiri, Eur. J. Inorg. Chem. (2007) 47114722.

[7] P. A. Dub, M. Rodriguez-Zubiri, J.-C. Daran, J.-J. Brunet, R. Poli, Organometallics 28 (2009) 4764-4777.

[8] P. A. Dub, M. Rodriguez-Zubiri, C. Baudequin, R. Poli, Green Chem. (2010) 13921396.

[9] H. M. Senn, P. E. Blochl, A. Togni, J. Am. Chem. Soc. 122 (2000) 4098-4107.

[10] P. A. Dub, R. Poli, J. Am. Chem Soc. (accepted).

[11] M. Green, J. K. K. Sarhan, I. M. Alnajjar, J. Chem. Soc., Dalton Trans. (1981) 1565-1571.

[12] A. De Renzi, B. Di Blasio, G. Morelli, A. Vitagliano, Inorg. Chim. Acta 63 (1982) 233-241.

[13] J. K. K. Sarhan, M. Green, I. M. Al-Najjar, J. Chem. Soc., Dalton Trans. (1984) 771-777.

[14] M. Green, J. K. K. Sarhan, I. M. Al-Najjar, Organometallics 3 (1984) 520-524.

[15] R. Pryadun, D. Sukumaran, R. Bogadi, J. D. Atwood, J. Am. Chem. Soc. 126 (2004) 12414-12420.

[16] G. Lorusso, C. R. Barone, N. G. Di Masi, C. Pacifico, L. Maresca, G. Natile, Eur. J. Inorg. Chem. (2007) 2144-2150.

[17] J. L. Mcbee, T. D. Tilley, Organometallics 29 (2010) 184-192.

[18] G. Balacco, G. Natile, J. Chem. Soc., Dalton Trans. (1990) 3021-3024.

[19] I. M. Al-Najjar, M. Green, J. Chem. Soc., Dalton Trans. (1979) 1651-1656.

[20] F. Pesa, M. Orchin, J. Organomet. Chem. 108 (1976) 135-138.

[21] P. A. Dub, R. Poli, J. Mol. Catal. A 324 (2010) 89-96.

[22] G. W. T. M. J. Frisch, H. B. Schlegel, G. E. Scuseria, M. A. Robb, J. R.

Cheeseman, J. Montgomery, J. A., T. Vreven, K. N. Kudin, J. C. Burant, J. M.

Millam, S. S. Iyengar, J. Tomasi, V. Barone, B. Mennucci, M. Cossi, G. Scalmani, N. Rega, G. A. Petersson, H. Nakatsuji, M. Hada, M. Ehara, K. Toyota, R. Fukuda, J. Hasegawa, M. Ishida, T. Nakajima, Y. Honda, O. Kitao, H. Nakai, M. Klene, X. Li, J. E. Knox, H. P. Hratchian, J. B. Cross, C. Adamo, J. Jaramillo, R. Gomperts, R. E. Stratmann, O. Yazyev, A. J. Austin, R. Cammi, C. Pomelli, J. W. Ochterski, P. Y. Ayala, K. Morokuma, G. A. Voth, P. Salvador, J. J. Dannenberg, V. G.

Zakrzewski, S. Dapprich, A. D. Daniels, M. C. Strain, O. Farkas, D. K. Malick, A. D. Rabuck, K. Raghavachari, J. B. Foresman, J. V. Ortiz, Q. Cui, A. G. Baboul, S. Clifford, J. Cioslowski, B. B. Stefanov, G. Liu, A. Liashenko, P. Piskorz, I.

Komaromi, R. L. Martin, D. J. Fox, T. Keith, M. A. Al-Laham, C. Y. Peng, A. Nanayakkara, M. Challacombe, P. M. W. Gill, B. Johnson, W. Chen, M. W. Wong, C. Gonzalez, J. A. Pople,, Gaussian 03, Revision C.02, Gaussian, Inc., Wallingford CT (2004).

[23] A. D. Becke, J. Chem. Phys. 98 (1993) 5648-5652.

[24] C. T. Lee, W. T. Yang, R. G. Parr, Phys. Rev. B 37 (1988) 785-789.

[25] B. Miehlich, A. Savin, H. Stoll, H. Preuss, Chem. Phys. Lett. 157 (1989) 200-206. 
[26] Y. Zhao, D. G. Truhlar, Acc. Chem. Res. 41 (2008) 157-167.

[27] L. E. Roy, P. J. Hay, R. L. Martin, J. Chem. Theory Comput. 4 (2008) 1029-1031.

[28] V. Barone, M. Cossi, J. Phys. Chem. A 102 (1998) 1995-2001.

[29] M. Cossi, N. Rega, G. Scalmani, V. Barone, J. Comput. Chem. 24 (2003) 669-681.

[30] Y. Takano, K. N. Houk, J. Chem. Theory Comput. 1 (2005) 70-77.

[31] A. Klamt, B. Mennucci, J. Tomasi, V. Barone, C. Curutchet, M. Orozco, F. J. Luque, Acc. Chem. Res. 42 (2009) 489-492.

[32] J. M. Ho, M. L. Coote, Theor. Chem. Acc. 125 (2010) 3-21.

[33] P. Winget, C. J. Cramer, D. G. Truhlar, Theor. Chem. Acc. 112 (2004) 217-227.

[34] A. Altomare, M. Burla, M. Camalli, G. Cascarano, C. Giacovazzo, A. Guagliardi, A. Moliterni, G. Polidori, R. Spagna, J. Appl. Cryst. 32 (1999) 115-119.

[35] G. M. Sheldrick, Acta Crystallogr., Sect. A: Found. Cryst. 64 (2008) 112-122.

[36] L. J. Farrugia, J. Appl. Crystallogr. 32 (1997) 565.

[37] J. R. L. Priqueler, I. S. Butler, F. D. Rochon, Applied Spectroscopy Reviews 41 (2006) 185-226.

[38] J. A. Pople, Mol. Phys. 1 (1958) 168-174.

[39] I. M. Ismail, S. J. S. Kerrison, P. J. Sadler, Polyhedron 1 (1982) 57-59.

[40] E. S. Gore, Magn. Reson. Chem. 39 (2001) 203-206.

[41] P. Courtot, A. Peron, R. Rumin, J. C. Chottard, D. Mansuy, J. Organomet. Chem. 99 (1975) C59-C62.

[42] J. Chatt, L. A. Duncanson, L. M. Venanzi, J. Chem. Soc. (1955) 4461-4469.

[43] J. Chatt, L. A. Duncanson, L. M. Venanzi, J. Chem. Soc. (1956) 2712-2725.

[44] J. Chatt, L. A. Duncanson, L. M. Venanzi, J. Inorg. Nucl. Chem. 8 (1958) 67-74.

[45] P. A. Dub, M. Baya, J. Houghton, N. V. Belkova, J. C. Daran, R. Poli, L. M.

Epstein, E. S. Shubina, Eur. J. Inorg. Chem. (2007) 2813-2826.

[46] A. Panunzi, A. De Renzi, R. Palumbo, G. Paiaro, J. Amer. Chem. Soc. 91 (1969) 3879-3883.

[47] A. Derenzi, G. Paiaro, A. Panunzi, V. Romano, Chim. Ind. (Milan) 55 (1973) 248251.

[48] L. Maresca, G. Natile, J. Chem. Soc., Dalton Trans. (1982) 1903-1906. 


\section{SYNOPSIS TOC}

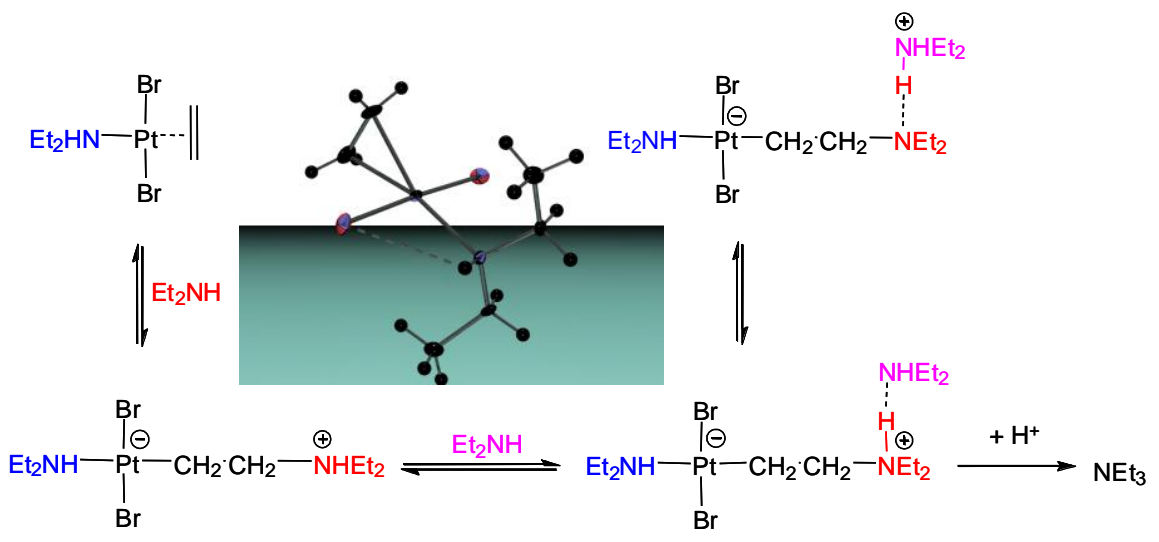

